Keywords: CSSX, cesium, solvent extraction

Retention: Permanent

\title{
Demonstration of the Next-Generation Caustic-Side Solvent Extraction Solvent with 2-cm Centrifugal Contactors using Tank 49H Waste and Waste Simulant
}

R. A. Pierce, T. B. Peters, M. L. Crowder, T. D. Caldwell, D. J. Pak, S. D. Fink, R. W. Blessing, and A. L. Washington

September 2011

Savannah River National Laboratory Savannah River Nuclear Solutions Aiken, SC 29808

Prepared for the U.S. Department of Energy under contract number DE-AC09-08SR22470.

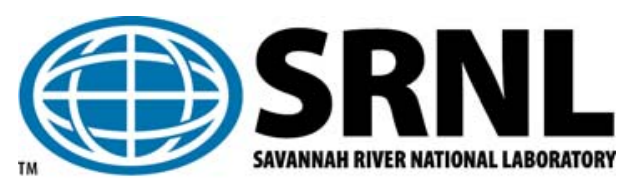




\section{DISCLAIMER}

This work was prepared under an agreement with and funded by the U.S. Government. Neither the U.S. Government or its employees, nor any of its contractors, subcontractors or their employees, makes any express or implied:

1. warranty or assumes any legal liability for the accuracy, completeness, or for the use or results of such use of any information, product, or process disclosed; or

2. representation that such use or results of such use would not infringe privately owned rights; or

3. endorsement or recommendation of any specifically identified commercial product, process, or service.

Any views and opinions of authors expressed in this work do not necessarily state or reflect those of the United States Government, or its contractors, or subcontractors.

\section{Printed in the United States of America}

Prepared for U.S. Department of Energy 


\section{REVIEWS AND APPROVALS}

AUTHORS:

R.A. Pierce, Separations and Actinide Science Programs

Date

T.B. Peters, Separations and Actinide Science Programs

Date

M.L. Crowder, Separations and Actinide Science Programs

Date

TECHNICAL REVIEW:

M.C. Thompson, Technical Reviewer

Date

Separations and Actinide Science Programs

M.W. Geeting, Technical Reviewer

Date

MCU Process Engineering

APPROVAL:

S.D. Fink, Manager and Co-author

Date

Separations and Actinide Science Programs

S.L. Marra, Manager

Date

Environmental \& Chemical Process Technology Research Programs

B.A. Oard, Manager

Date

MCU Life Extension/NGS 


\section{EXECUTIVE SUMMARY}

Researchers successfully demonstrated the chemistry and process equipment of the Caustic-Side Solvent Extraction (CSSX) flowsheet using MaxCalix for the decontamination of high level waste (HLW). The demonstration was completed using a 12-stage, 2-cm centrifugal contactor apparatus at the Savannah River National Laboratory (SRNL). This represents the first CSSX process demonstration of the MaxCalix solvent system with Savannah River Site (SRS) HLW. Two tests lasting 24 and 27 hours processed non-radioactive simulated Tank 49H waste and actual Tank 49H HLW, respectively. Conclusions from this work include the following.

- The CSSX process is capable of reducing ${ }^{137}$ Cs in high level radioactive waste by a factor of more than 40,000 using five extraction, two scrub, and five strip stages.

- Tests demonstrated extraction and strip section stage efficiencies of greater than $93 \%$ for the Tank $49 \mathrm{H}$ waste test and greater than $88 \%$ for the simulant waste test.

- During a test with HLW, researchers processed 39 liters of Tank 49H solution and the waste raffinate had an average decontamination factor (DF) of $6.78 \mathrm{E}+04$, with a maximum of $1.08 \mathrm{E}+05$. A simulant waste solution ( $\sim 34.5$ liters) with an initial Cs concentration of $83.1 \mathrm{mg} / \mathrm{L}$ was processed and had an average DF greater than 5.9E+03, with a maximum DF of greater than $6.6 \mathrm{E}+03$. The difference may be attributable to differences in contactor stage efficiencies.

- Test results showed the solvent can be stripped of cesium and recycled for $\sim 25$ solvent turnovers without the occurrence of any measurable solvent degradation or negative effects from minor components.

- $\quad$ Based on the performance of the 12-stage 2-cm apparatus with the Tank 49H HLW, the projected DF for MCU with seven extraction, two scrub, and seven strip stages operating at a nominal efficiency of $90 \%$ is $~ 388,000$. At 95\% stage efficiency, the DF in MCU would be 3.2 million.

- Carryover of organic solvent in aqueous streams (and aqueous in organic streams) was less than $0.1 \%$ when processing Tank $49 \mathrm{H}$ HLW.

- The entrained solvent concentration measured in the decontaminated salt solution (DSS) was as much as $\sim 140 \mathrm{mg} / \mathrm{L}$, although that value may be overstated by as much as $50 \%$ due to modifier solubility in the DSS.

- The entrained solvent concentration was measured in the strip effluent (SE) and the results are pending.

- A steady-state concentration factor (CF) of 15.9 was achieved with Tank 49H HLW.

- Cesium distribution ratios [D(Cs)] were measured with non-radioactive Tank 49H waste simulant and actual Tank $49 \mathrm{H}$ waste. Below is a comparison of $\mathrm{D}(\mathrm{Cs})$ values of ESS and 2-cm tests. 
- Batch Extraction-Strip-Scrub (ESS) tests yielded D(Cs) values for extraction of $\sim 81-88$ for tests with Tank $49 \mathrm{H}$ waste and waste simulant. The results from the 2-cm contactor tests were in agreement with values of 58-92 for the Tank 49H HLW test and 54-83 for the simulant waste test. These values are consistent with the reference $\mathrm{D}(\mathrm{Cs})$ for extraction of $\sim 60$.

- In tests with Tank $49 \mathrm{H}$ waste and waste simulant, batch ESS tests measured $\mathrm{D}(\mathrm{Cs})$ values for the two scrub stages as $~ 3.5-5.0$ for the first scrub stage and $\sim 1.0-3.0$ for the second scrub stage. In the Tank $49 \mathrm{H}$ test, the $\mathrm{D}(\mathrm{Cs})$ values for the 2-cm test were far from the ESS values. A D(Cs) value of 161 was measured for the first scrub stage and 10.8 for the second scrub stage. The data suggest that the scrub stage is not operating as effectively as intended. For the simulant test, a $\mathrm{D}(\mathrm{Cs})$ value of 1.9 was measured for the first scrub stage; the sample from the second scrub stage was compromised. Measurements of the $\mathrm{pH}$ of all stage samples for the Tank $49 \mathrm{H}$ test showed that the $\mathrm{pH}$ for extraction and scrub stages was 14 and the $\mathrm{pH}$ for the strip stages was $\sim 7$. It is expected that the $\mathrm{pH}$ of the second scrub stage would be $\sim 12-13$.

- Batch ESS tests measured $\mathrm{D}(\mathrm{Cs})$ values for the strip stages to be $\sim 0.002-0.010$. A high value in Strip \#3 of a test with simulant solution has been attributed to issues associated with the limits of detection for the analytical method. In the 2-cm contactor tests, the first four strip stages of the Tank $49 \mathrm{H}$ waste test and all five strip stages in the simulant waste test had higher values than the ESS tests. Only the fifth strip stage $D(C s)$ value of the Tank $49 \mathrm{H}$ waste test matched that of the ESS tests. It is speculated that the less-than-optimal performance of the strip section is caused by inefficiencies in the scrub section. Because strip is sensitive to $\mathrm{pH}$, the elevated $\mathrm{pH}$ value in the second scrub stage may be the cause of strip performance.

- In spite of the $\mathrm{D}(\mathrm{Cs})$ values obtained in the scrub and strip sections, testing showed that the solvent system is robust. Average DFs for the process far exceeded targets even though the scrub and strip stages did not function optimally. Correction of the issue in the scrub and strip stages is expected to yield even higher waste DFs. However, in light of the high DFs already achieved, a higher DF represents only a small improvement in Cs removal. For higher-activity waste feeds, the impact of optimal scrub and strip operation may be more pronounced. 


\section{TABLE OF CONTENTS}

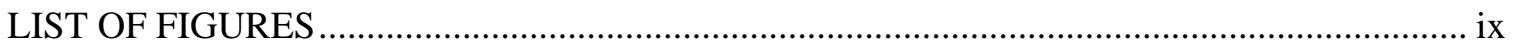

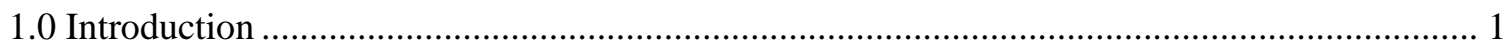

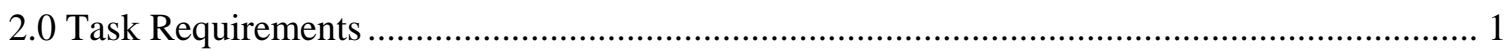

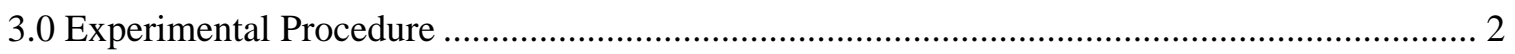

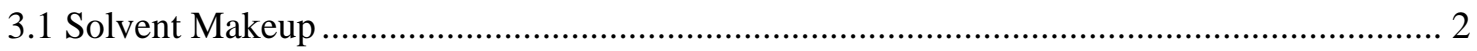

3.2 Simulant Feed Makeup and Compositions ...................................................................... 2

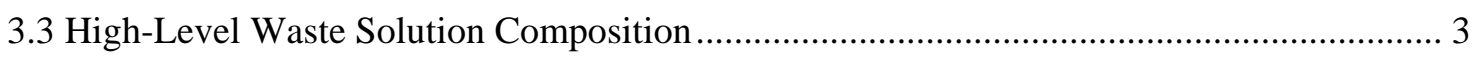

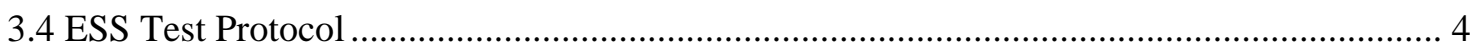

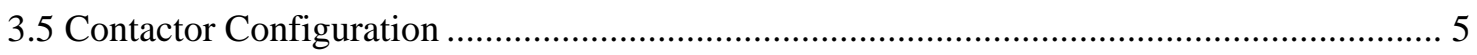

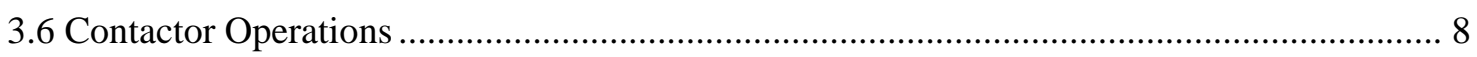

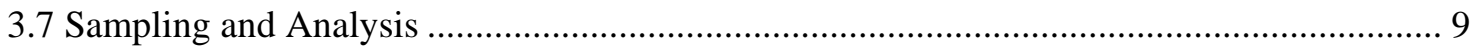

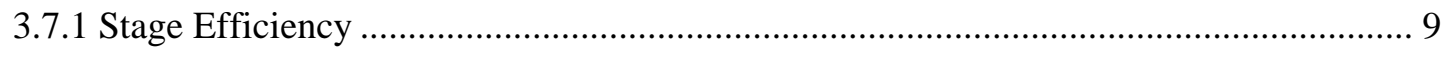

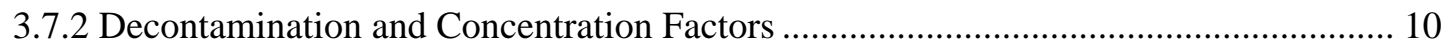

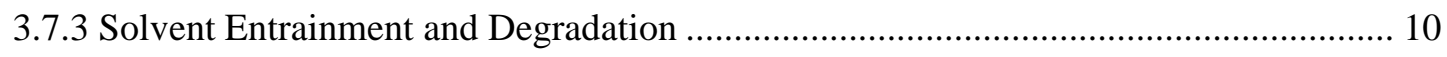

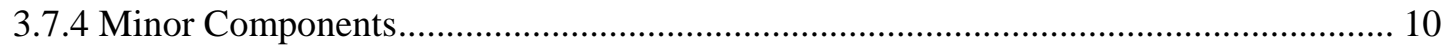

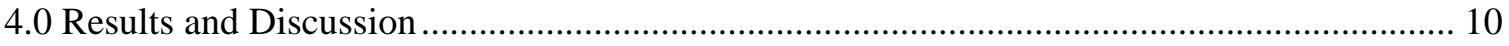

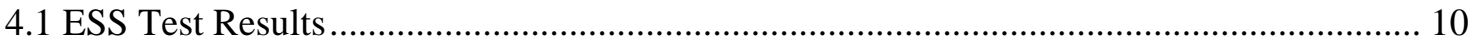

4.2 Non-Radioactive Simulant Testing with Centrifugal Contactors ....................................... 11

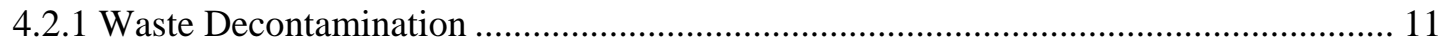

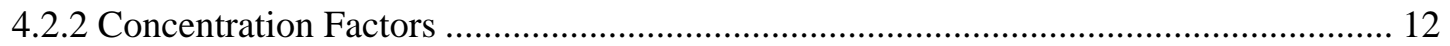

4.2.3 Distribution of Inorganic Components......................................................................... 14

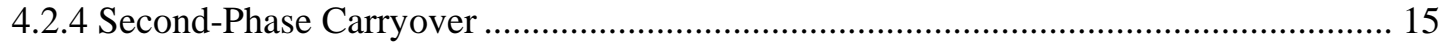

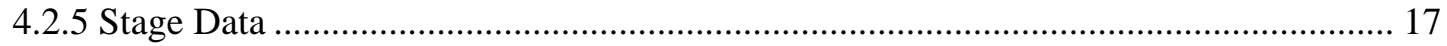

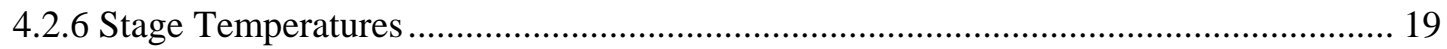

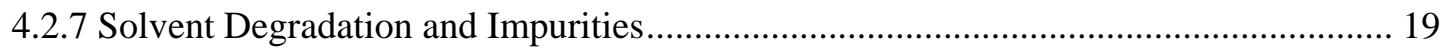

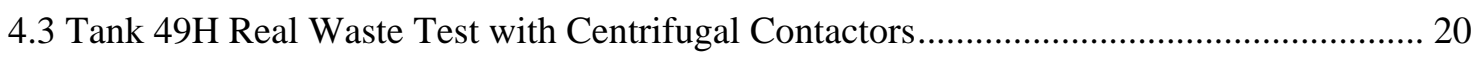

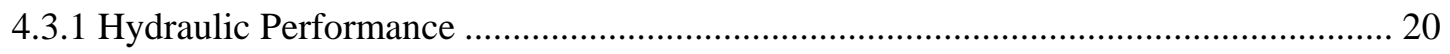

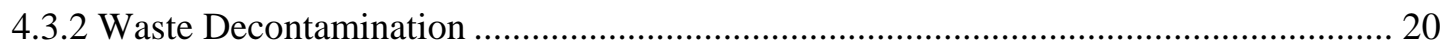

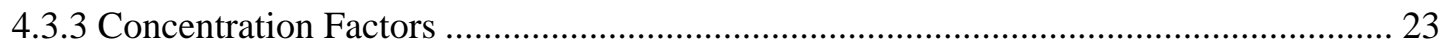

4.3.4 Concentration of Inorganic Components in the Solvent ............................................. 24

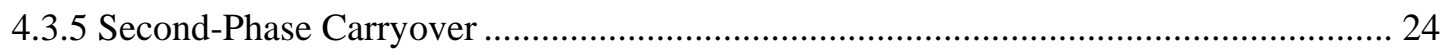

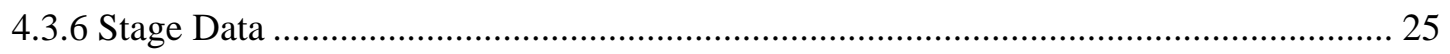

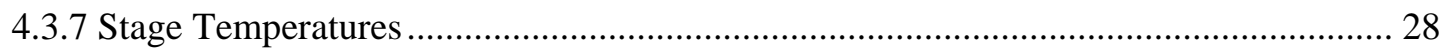




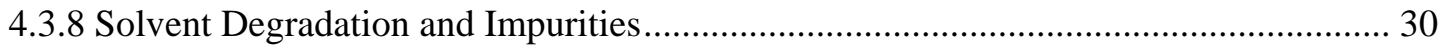

5.0 Assessment of Process Performance ……................................................................................... 31

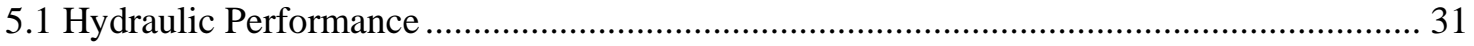

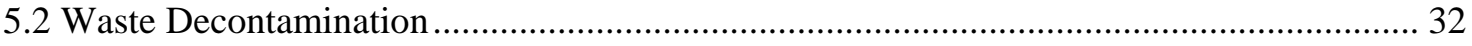

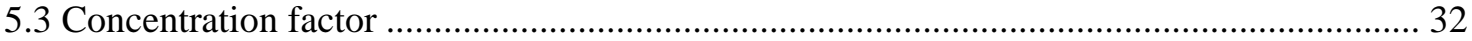

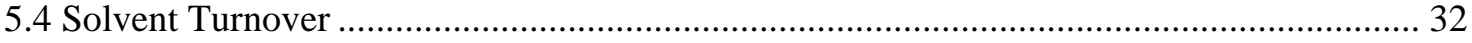

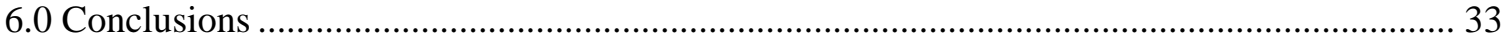

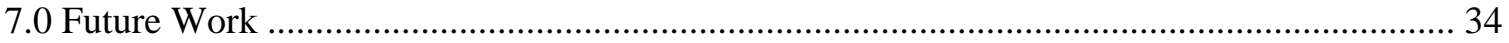

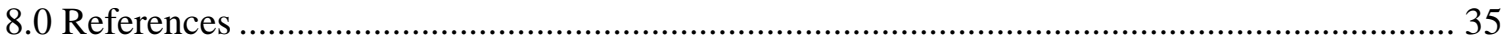

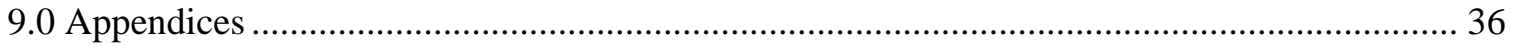

9.1 Appendix A. Preparation of 45 Liters of Tank 49H Simulant Salt Solution ...................... 36

9.2 Appendix B. Simulant Test Concentration of Inorganic Components (in $\mathrm{mg} / \mathrm{L}$ ) in Stage

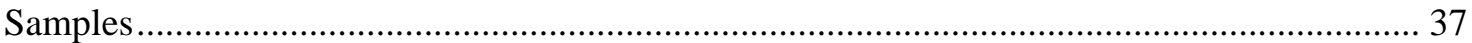




\section{LIST OF TABLES}

Table 3-1. Composition of Tank 49H Simulated Waste Solutions .............................................. 3

Table 3-2. Origin of Tank 49H Sample...................................................................................... 3

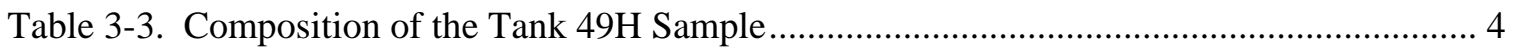

Table 3-4. Organic:Aqueous Volume Ratios in Previous and Current ESS Tests ........................ 5

Table 4-1. Cesium Distribution Ratios for the ESS Tests ............................................................ 10

Table 4-2. Feed Rate Setpoints and Observed Flowrates for Non-Radioactive Test ................... 11

Table 4-3. DSS Data for Non-Radioactive Simulant Test.......................................................... 12

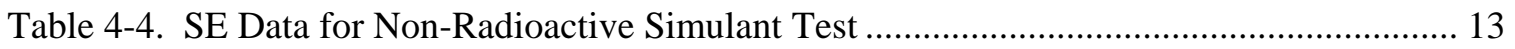

Table 4-5. Distribution of Inorganic Components (in mg/L) as a Function of Time ................... 15

Table 4-6. Simulant Test Organic Carry Over into the DSS and SE Streams.............................. 16

Table 4-7. Non-Radioactive Simulant Test Second-Phase Carryover Rates................................ 16

Table 4-8. Equilibrium Distribution Ratios for Non-Radioactive Test ....................................... 17

Table 4-9. Analyses of Solvent - Before and After Simulant Test (mg/L)................................ 19

Table 4-10. Feed Rate Setpoints and Observed Feed Rates for Tank 49H HLW Test ................ 20

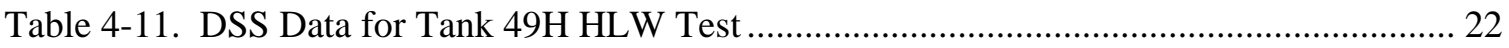

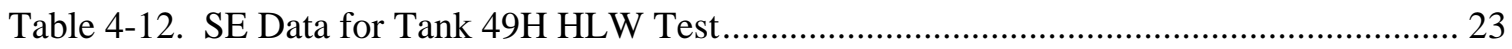

Table 4-13. Inorganic Compositions in the Solvent for Tank 49H HLW Test ........................... 24

Table 4-14. Tank 49H HLW Test Organic Carry Over into the DSS and SE Streams ................ 25

Table 4-15. Tank 49H HLW Test Second-Phase Carryover Rates ............................................. 25

Table 4-16. Equilibrium Distribution Ratios for Tank 49H HLW Test ...................................... 26

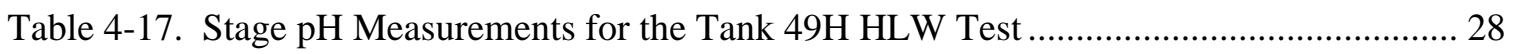

Table 4-18. Analyses of Solvent - Before and After Tank 49H HLW Test (mg/L) .................... 30

Table 5-1. Measured DF Values for Simulant and Tank 49H Tests ........................................ 32 


\section{LIST OF FIGURES}

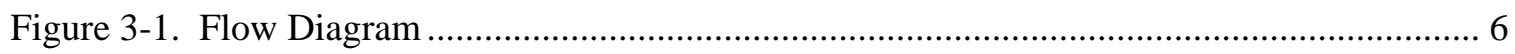

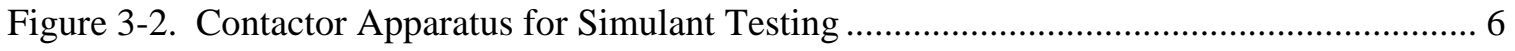

Figure 3-3. Contactor Apparatus in SRNL Shielded Cells Facility .............................................. 8

Figure 4-1. Decontamination Factors for the Non-Radioactive Test .......................................... 12

Figure 4-2. Concentration Factors for the Non-Radioactive Simulant Test ................................ 13

Figure 4-3. Outlet Stream Decanters Depicting Second-Phase Carryover ................................. 16

Figure 4-4. Stage Sample Data for the Non-Radioactive Simulant Test.................................... 18

Figure 4-5. FTIR Analyses of Solvent from Simulant Test ...................................................... 19

Figure 4-6. FTIR Spectra Difference Analysis of Solvent from Simulant Test .......................... 20

Figure 4-7. Decontamination Factors for the Tank 49H HLW Test........................................... 22

Figure 4-8. Concentration Factors for the Tank 49H HLW Test ............................................... 23

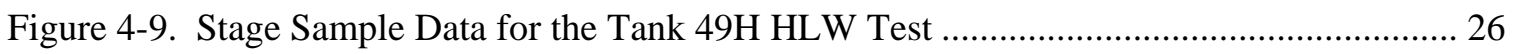

Figure 4-10. Comparison of Tank 49H HLW Test Data with “Good” Scrub-Strip Values ......... 27

Figure 4-11. Comparison of Contactor Block and Flow Temperatures .................................... 29

Figure 4-12. Comparison of Contactor Stage Temperatures for Tank 49H HLW Test ............... 30 


\section{LIST OF ABBREVIATIONS}

$\mathrm{AD}$

ANL

$\mathrm{CF}$

CSSX

DF

DSS

DWPF

FTIR

HLW

HPLC

ICPES

ICPMS

MCU

NGCS

ORNL

SASSE

SE

SRNL

SRS

SVOA

TBD

TDD

VOA
Analytical Development

Argonne National Laboratory

concentration factor

Caustic Side Solvent Extraction

decontamination factor

decontaminated salt solution

Defense Waste Processing Facility

Fourier Transform Infrared

high level waste

high performance liquid chromatography

inductively coupled plasma emission spectroscopy

inductively coupled plasma mass spectroscopy

Modular CSSX Unit

Next-Generation CSSX Solvent

Oak Ridge National Laboratory

Spreadsheet Algorithm for Stagewise Solvent Extraction

strip effluent

Savannah River National Laboratory

Savannah River Site

semi-volatile organic analysis

to be determine

Technology Development and Deployment

volatile organic analysis 


\subsection{Introduction}

A solvent extraction system for removal of cesium from alkaline solutions was developed utilizing a novel solvent invented at the Oak Ridge National Laboratory (ORNL). ${ }^{[1]}$ This solvent consists of a calix[4]arene-crown-6 extractant dissolved in an inert hydrocarbon matrix. A modifier is added to the solvent to enhance the extraction power of the calixarene and to prevent the formation of a third phase. An additional additive is used to improve stripping performance and to mitigate the effects of any surfactants present in the feed stream. ${ }^{[2]}$ The process that deploys this solvent system is known as Caustic Side Solvent Extraction (CSSX). The solvent system has been deployed at the Savannah River Site (SRS) in the Modular CSSX Unit (MCU) since 2008.

The MCU uses centrifugal contactors (10-in for extraction stages and 5-in for scrub and strip stages) to provide mechanical mixing and phase separation between the solvent and alkaline waste solutions by way of two separations. The first separation extracts cesium from the waste solutions into the solvent system; the second separation strips the cesium from the solvent system while providing a nominal cesium concentration factor of 15 . From its radioactive start-up in April 2008 until the end of August 2011, MCU processed approximately 2 million gallons of HLW solution for disposition. The decontaminated salt solution is sent to the SRS Saltstone Facility and the concentrated cesium stream is transferred to DWPF.

Subsequent development efforts by ORNL have identified an improved solvent system that can raise the expected decontamination factor (DF) in MCU from $\sim 200$ to more than $40,000 .{ }^{[3]}$ The improved DF is attributed to an increased distribution ratio for cesium (DCs) in extraction from $\sim 15$ to $\sim 60$, an increased solubility of the calixarene in the solvent from $0.007 \mathrm{M}$ to $>0.050 \mathrm{M}$, and use of boric acid $\left(\mathrm{H}_{3} \mathrm{BO}_{3}\right)$ stripping that yields $\mathrm{D}(\mathrm{Cs})$ values less than 0.01 . The improved solvent system contains four components: 1) $0.050 \mathrm{M}$ 1,3-alt-25,27-Bis(3,7-dimethyloctyloxy) calix[4]arene-benzocrown-6, also known as MaxCalix, is the extractant; 2) $0.50 \mathrm{M} 1-(2,2,3,3-$ tetrafluoropropoxy)-3-(4-sec-butylphenoxy)-2-propanol, or Cs-7SB, is the modifier; 3) $0.003 \mathrm{M}$ $N, N$ '-dicyclohexyl-N"-isotridecylguanidine, or DCiTDG, is the suppressor; and 4) $\mathrm{C}_{12}$-isoparaffinic hydrocarbon, or Isopar ${ }^{\circledR} \mathrm{L}$, is the diluent. The modified solvent system is referred to as the Next Generation CSSX Solvent (NGCS).

The solvent development involves several tasks with the objective being a deployment of NGCS in MCU in the time frame of CY2012 and subsequent deployment in the Salt Waste Processing Facility (in 2015). This report summarizes the results of 2-cm centrifugal contactor flow tests at SRNL with non-radioactive simulated waste and Tank $49 \mathrm{H}$ radioactive waste. A 24-hour nonradioactive test with Tank $49 \mathrm{H}$ simulated waste was completed to test the hydraulic operation of process equipment and verify the performance of the solvent system. A 27-hour radioactive test with actual Tank $49 \mathrm{H}$ waste was performed in the SRNL Shielded Cells facility approximately nine weeks after the non-radioactive test.

\subsection{Task Requirements}

Success criteria for the 2-cm centrifugal contactor flow tests are provided in the EM-30 Technology Develop and Deployment (TDD) Program Task Plan. ${ }^{[4]}$ The success criteria and other self-imposed requirements for the flow tests are listed below.

- Use high level radioactive waste from Tank $49 H$.

- Filter the waste solution prior to processing in the contactors. 
- Operate the process for at least 20 solvent turnovers.

- Operate for at least 24 hours at a waste feed rate of $24 \mathrm{~mL} / \mathrm{min}+/-20 \%$ (39 L feed available) with:

- initial solvent inventory of $450 \mathrm{~mL}+/-50 \mathrm{~mL}$,

- solvent flow rate of $6 \mathrm{~mL} / \mathrm{min}+/-20 \%$,

- $\quad$ scrub flow rate of $1.6 \mathrm{~mL} / \mathrm{min}+/-20 \%$, and

- $\quad$ strip flow rate of $1.6 \mathrm{~mL} / \mathrm{min}+/-20 \%$.

- Measure second-phase entrainment.

- Operate extraction-stage temperatures at $23 \pm 3{ }^{\circ} \mathrm{C}$.

- Operate strip-stage temperatures at $33 \pm 3{ }^{\circ} \mathrm{C}$.

- Demonstrate an MCU equivalent decontamination factor of $\geq 40,000$ (assuming a 90\% extraction-stage efficiency).

- Demonstrate a Cs concentration factor of 15.

\subsection{Experimental Procedure}

\subsection{Solvent Makeup}

A single 1-liter batch of solvent was prepared for the 2-cm contactor tests. To a 1-liter Teflon ${ }^{\mathrm{TM}}$ bottle, $1.22 \mathrm{~g}$ of DCiTDG (guanidine), $169.18 \mathrm{~g}$ of Cs-7B modifier, and $47.84 \mathrm{~g}$ of MaxCalix were added. To the Teflon ${ }^{\mathrm{TM}}$ bottle, $253.46 \mathrm{~g}$ of Isopar $\mathrm{L}$ were added. The bottle was capped and gently shaken until the MaxCalix solids dissolved. The contents of the bottle were transferred to a previously-weighed 1-liter volumetric flask. Isopar L was added until the volume in the flask was 1 liter. The final weight of chemicals added to the flask was $835.04 \mathrm{~g}$. The solvent in the flask was transferred back to the 1-liter Teflon ${ }^{\mathrm{TM}}$ bottle. The solvent was used as-is without further qualification in an ESS test. Each 2-cm contactor test used a fresh aliquot of solvent from this batch of solvent. The ESS tests described in Section 3.4 used solvent from a different source batch but of the same approximate composition.

\subsection{Simulant Feed Makeup and Compositions}

One non-radioactive waste simulant was prepared for use during the Tank $49 \mathrm{H}$ waste testing. The simulant chemically approximated the waste from Tank $49 \mathrm{H}$ with the exception of minor metal and organic compounds. The purpose of the simulant was to provide non-radioactive feed for verifying proper hydraulic operation of the contactor test apparatus and for "spiking" known amounts of ${ }^{137} \mathrm{Cs}$ to verify decontamination and concentration factors. A 45-liter batch of the simulant was prepared as a cesium-free solution. Once prepared and filtered, four liters of the simulant batch was separated and maintained cesium free. The purpose of maintaining the cesium-free portions of the simulants was to provide a solution that contained no cesium that could be pumped through the test apparatus while solution flows were established during startup. Cesium chloride was added to the remaining 41 liters of simulant solution to provide Cs (nonradioactive) at a concentration ( $\sim 83 \mathrm{mg} / \mathrm{L})$ high enough to measure a DF of at least 5000.

The method for preparation of the simulant solution is provided in Section 9.1, Appendix A. Calculated concentrations of the primary components are listed in Table 3-1. 
Table 3-1. Composition of Tank 49H Simulated Waste Solutions

\begin{tabular}{|c|c|c|c|}
\hline Component & Concentration (M) & Component & Concentration (M) \\
\hline $\mathrm{Na}^{+}$ & 6.5 & $\mathrm{CO}_{3}{ }^{2-}$ & 0.25 \\
\hline $\mathrm{K}^{+}$ & 0.013 & $\mathrm{SO}_{4}{ }^{2-}$ & 0.057 \\
\hline $\mathrm{Cs}^{+}$ & $0.00085 *$ & $\mathrm{Cl}^{-}$ & $0.00085 *$ \\
\hline $\mathrm{OH}^{-}$ & 2.65 & $\mathrm{PO}_{4}^{3-}$ & 0.0047 \\
\hline $\mathrm{NO}_{3}^{-}$ & 2.29 & $\mathrm{C}_{2} \mathrm{O}_{4}{ }^{2-}$ & 0.0013 \\
\hline $\mathrm{NO}_{2}^{-}$ & 0.65 & $\mathrm{SiO}_{3}^{2-}$ & 0.0046 \\
\hline $\mathrm{AlO}_{2}^{-}$ & 0.19 & $\mathrm{COOH}^{-}$ & 0.021 \\
\hline
\end{tabular}

\subsection{High-Level Waste Solution Composition}

SRS tank farm personnel provided a sample of liquid radioactive waste from Tank $49 \mathrm{H}$. The waste is from the period of MCU operation referred to as Macrobatch 3 (i.e., the third major operating campaign). Tank $49 \mathrm{H}$ is a mixture of material from several other tanks $(21 \mathrm{H}, 23 \mathrm{H}$, and $24 \mathrm{H})$. Portions of the supernatant liquid were obtained in 3-liter sample carboys. The samples were received, stored, and handled in the SRNL Shielded Cells. Table 3-2 summarizes source information for the sample.

Table 3-2. Origin of Tank $49 H$ Sample

\begin{tabular}{|l|l|}
\hline Source & Tank 49H \\
\hline Date Sampled & Dec. 2010 to Feb. 2011 \\
\hline Tank Farm Identification & HTF-49-10-167, -175 \\
& HTF-49-11-9, -11, -12, -15, -16 \\
& $-17,-18,-19,-20,-21,-22$ \\
\hline Date received at SRNL & Dec. 2010 to Feb. 2011 \\
\hline Approximate volume (L) & 39 \\
\hline
\end{tabular}

The Tank 49H material was delivered in thirteen, 3L quantities over the period of December 10, 2010 to February 9, 2011. Each of the thirteen samples was examined for evidence of solids or other unusual characteristics. None were found, and all thirteen samples were combined into a 50-L carboy. A 400-mL aliquot of the Tank 49H sample was removed for sorption testing of monosodium titanate. (The sorption testing is discussed in a separate report.)

The solution density was measured using a $2 \mathrm{~mL}$ volumetric density tube weighed on a balance sensitive to $\pm 0.001 \mathrm{~g}$. Samples of the Tank $49 \mathrm{H}$ composite were analyzed without any filtering or other alterations. These analyses (Table 3-3) were not intended as an exhaustive analysis of the constituents, but rather to confirm the general nature of the material. 
The waste composition is typical of tank supernates. Crystallization of less soluble salts leaves the supernate highly concentrated in sodium hydroxide. In these solutions the free hydroxide accounts for half or more of the total sodium concentration. Cesium also tends to concentrate in the supernate. This is reflected in the high ${ }^{137} \mathrm{Cs}$ activity of the sample $(1.44 \mathrm{E}+08 \mathrm{dpm} / \mathrm{mL})$. Potassium (K) ion $(505 \mathrm{mg} / \mathrm{L})$ and rubidium $(\mathrm{Rb})$ ion $(0.476 \mathrm{mg} / \mathrm{L})$, which compete with Cs during extraction, ${ }^{[5]}$ are also present. To date, studies have not been completed to evaluate the effect of $\mathrm{Rb}$ on Cs removal.

Table 3-3. Composition of the Tank 49H Sample

\begin{tabular}{|c|c|c|}
\hline Analyte & Concentration (mg/L) & $\begin{array}{c}\text { Method \% } \\
\text { Uncertainty }\end{array}$ \\
\hline $\mathrm{Na}^{+}$ & 150,000 & 10 \\
\hline $\mathrm{K}^{+}$ & 505 & 10 \\
\hline $\mathrm{Rb}^{+}$ & 0.476 & 20 \\
\hline $\mathrm{Cs}^{+}$ & 2.09 & 20 \\
\hline Free OH & $2.65(\mathrm{M})$ & 10 \\
\hline $\mathrm{NO}_{3}{ }^{-}$ & 188,000 & 10 \\
\hline $\mathrm{NO}_{2}{ }^{-}$ & 4160 & 10 \\
\hline $\mathrm{Al}^{3+}$ & 5110 & 10 \\
\hline $\mathrm{SO}_{4}{ }^{2-}$ & 6490 & 10 \\
\hline $\mathrm{PO}_{4}{ }^{3-}$ & 874 & 10 \\
\hline $\left.\mathrm{CO}_{3}{ }^{2-}\right)$ & $0.239(\mathrm{M})$ & 10 \\
\hline $\mathrm{F}^{-}$ & $<100$ & 10 \\
\hline $\mathrm{Cl}^{-}$ & 373 & 10 \\
\hline $0 x a l a t e$ & 175 & 10 \\
\hline formate & 919 & 10 \\
\hline${ }^{137} \mathrm{Cs}$ & $1.44 \mathrm{E}+08(\mathrm{dpm} / \mathrm{mL})$ & 5.00 \\
\hline${ }^{90} \mathrm{Sr}$ & $3.57 \mathrm{E}+05(\mathrm{dpm} / \mathrm{mL})$ & 9.41 \\
\hline${ }^{238} \mathrm{Pu}$ & $6.76 \mathrm{E}+04(\mathrm{dpm} / \mathrm{mL})$ & 5.64 \\
\hline${ }^{239 / 40} \mathrm{Pu}$ & $1.27 \mathrm{E}+04(\mathrm{dpm} / \mathrm{mL})$ & 5.67 \\
\hline Mass-235 & $0.183 \mu \mathrm{g} / \mathrm{L}$ & 20 \\
\hline Mass-238 & 26.1 & 20 \\
\hline Density & $1.269 \mathrm{~g} / \mathrm{mL}$ & 10 \\
\hline & & \\
\hline & & \\
\hline
\end{tabular}

\subsection{ESS Test Protocol}

As a confirmation of the non-radioactive 2-cm demonstration, SRNL also performed an Extraction-Scrub-Strip (ESS) test, using the same solvent and aqueous feed materials. For these test, the researchers used a nominal starting volume of $120 \mathrm{~mL}$ of Tank $49 \mathrm{H}$ waste (or $90 \mathrm{~mL}$ of waste simulant) aqueous feed and $40 \mathrm{~mL}$ of fresh, unused next-generation solvent (30 mL of solvent for waste simulant test). This test uses the same protocol as used in the previous ESS testing. ${ }^{[6]}$ The only changes from this protocol were in the aqueous:organic volume ratios (Table 3-4). 
Table 3-4. Organic:Aqueous Volume Ratios in Previous and Current ESS Tests

\begin{tabular}{|c|c|c|c|}
\hline \multicolumn{2}{|c|}{ Previous ESS Test } & \multicolumn{2}{c|}{ Current ESS Test } \\
\hline Step & Volume Ratio & Step & Volume Ratio \\
\hline Extraction & $1: 3$ & Extraction & $1: 4$ \\
\hline Scrub & $5: 1$ & Scrub & $3.75: 1$ \\
\hline Strip & $5: 1$ & Strip & $3.75: 1$ \\
\hline
\end{tabular}

The ESS test is a series of organic (solvent)-aqueous (Tank $49 \mathrm{H}$ solution) contacts. There are two extraction steps, two scrub steps, and three strip steps. Between each step we separate the phases, remove a portion of each phase for analysis, and place one of the phases back in the funnel and contact it with a new organic or aqueous phase. The two phases are shaken for two minutes and then allowed to contact for $\sim 24$ hours before proceeding to the next step. The Cs concentration for the non-radioactive ESS tests was determined using inductively coupled plasma mass spectroscopy (ICPMS).

\subsection{Contactor Configuration}

The process equipment used for these tests centered on 12 stages of 316 stainless-steel, 2-cm annular centrifugal contactors designed and fabricated by Argonne National Laboratory (ANL). The contactors were grouped into five extraction stages, two scrub stages, and five strip stages in a single-tiered configuration (Figure 3-1). Inter-stage lines were stainless steel to promote improved wetting and flow characteristics (Figure 3-2). The tubing runs for feed lines were made of polypropylene.

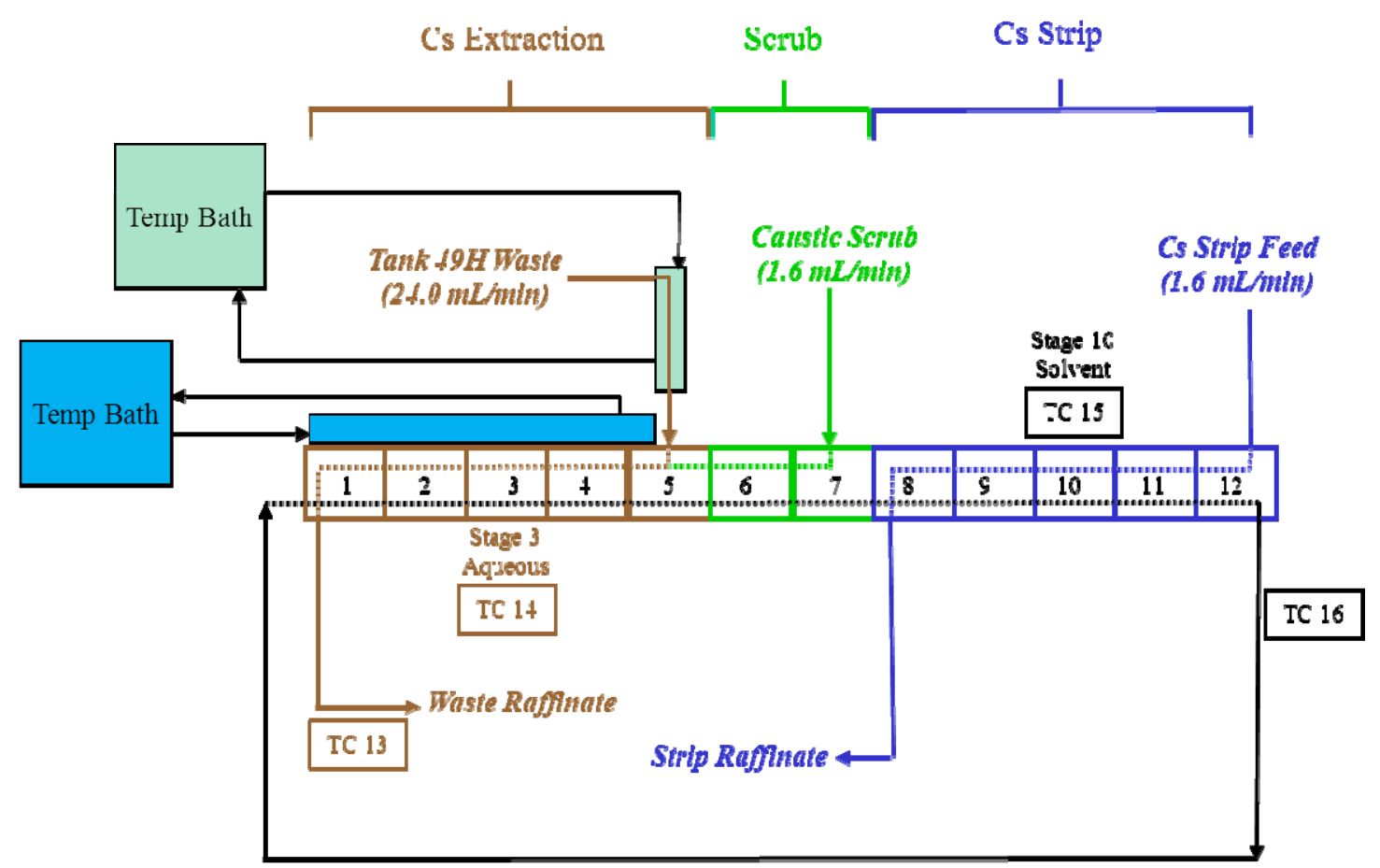

Solvent $(6.0 \mathrm{~mL} / \mathrm{mln})$ 
Figure 3-1. Flow Diagram

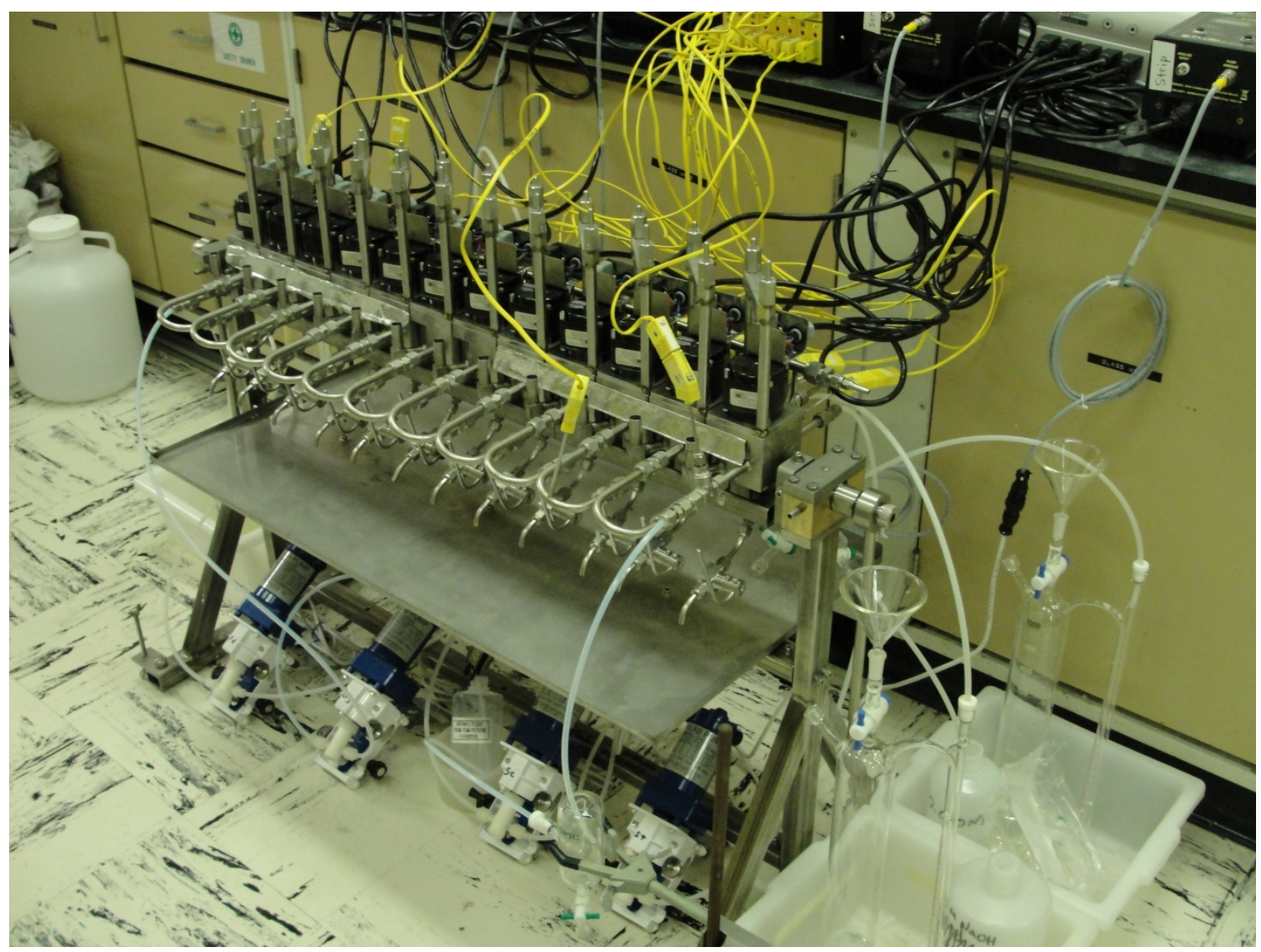

Figure 3-2. Contactor Apparatus for Simulant Testing

Physical dimensions of the contactors are specified on ANL print number CMT-E1265 titled "2-cm Contactor" and dated January 6, 1994. To improve stage efficiency, the hole diameter at the bottom of each rotor was increased to make the rotor partially-pumping. The aqueous weirs for the rotors in all stages were $0.491 / 0.492$ inches to support total flow rates of approximately 60 $\mathrm{mL} / \mathrm{min}^{\left[{ }^{[7]}\right.}$ Motor shafts were lengthened from previous designs to allow visual verification of rotation.

To maintain the temperature of the extraction section at $23 \pm 3{ }^{\circ} \mathrm{C}$, a section of $3 / 4$ " square stainless steel tube was pressed against the bodies of the five extraction stages (Stage 1-5). The stainless steel tube had an inlet and outlet for flowing chilled water through the tube, entering at Stage 1 and exiting at Stage 5. Chilled water was supplied from a ThermoCube Model 400 solid-state cooling/heating unit. Due to the temperature $\left(\sim 30^{\circ} \mathrm{C}\right)$ in the Shielded Cells on the day of the test, the Tank $49 \mathrm{H}$ solution (fed into Stage 5) was also cooled using a small glass heat exchanger. Chilled water for the feed-stream heat exchanger was supplied from a separate ThermoCube Model 400 cooling/heating unit.

During the non-radioactive simulant test, a similar square stainless steel tube was used to control the temperature of the strip section at $33 \pm 3{ }^{\circ} \mathrm{C}$. However, in the radioactive test, the need to cool the extraction section took priority over control of the strip section temperature, and the cooling/heating unit dedicated for strip section temperature control was used to cool the Tank $49 \mathrm{H}$ feed solution. The temperatures of the strip stages were not controlled, but results 
from the non-radioactive test provided an expectation that the strip stage temperatures would be maintained at or near the desired range of $33 \pm 3^{\circ} \mathrm{C}$ in this modified configuration.

Type K (Omega Engineering) thermocouples were attached to the contactor bodies for all 12 stages to provide temperature monitoring. Additionally, Type K thermocouples were installed to monitor liquid temperatures in four locations: 1) aqueous stream exiting Stage 1,2) aqueous stream flowing from Stage 3 to Stage 2, 3) organic stream flowing from Stage 10 to Stage 11, and 4) organic stream exiting Stage 12. It should be noted that heat generated by the centrifugal contactor motors conducted into the contactor bodies. This led to discrepancies between the temperature measurements of the contactor bodies and the liquids (i.e., the contactor bodies were hotter than the temperature-controlled circulating fluids). During non-radioactive testing, it was determined that the four liquid temperatures were the more reliable process fluid values and should be used as the basis for control decisions.

Liquids were fed to the contactors using pumps manufactured by Fluid Metering, Inc. (FMI). All aqueous feed streams were fed from graduated glass feed vessels. Changes in volume over time were used as the primary method of flow rate monitoring. Each of the feed vessels was equipped with a side arm that could be used for an immediate flow rate measurement if the primary method indicated a possible discrepancy. The flow rate of the solvent stream was measured using grab samples. Flow rates were verified every $30 \mathrm{~min}$.

Temperature data were recorded every $30 \mathrm{~s}$ to a workstation running National Instruments Measurement and Automation Explorer 4.7.7 process monitoring software. Feed rate and chiller set-point data were manually recorded and later added to the file containing the temperature data.

The waste feed for the simulant tests was filtered prior to delivery of the simulant solution to the laboratory. The Tank $49 \mathrm{H}$ waste was filtered through an 8-micron Parker Balston cartridge filter as it was being added to the Waste Feed vessel. The exit streams from the contactors were equipped with aqueous-solvent decanters (fabricated in the SRNL Glass Shop) to disengage the liquid phases and observe second-phase carryover.

The hydraulic verification tests using the non-radioactive Tank $49 \mathrm{H}$ simulated waste were performed first in SRNL laboratory 773-A, C151 (Figure 3-2), and then in the SRNL Shielded Cells mockup facility. The Tank 49H waste tests were performed in Cells 7 and 8 of the SRNL Shielded Cells Facility (Figure 3-3). 


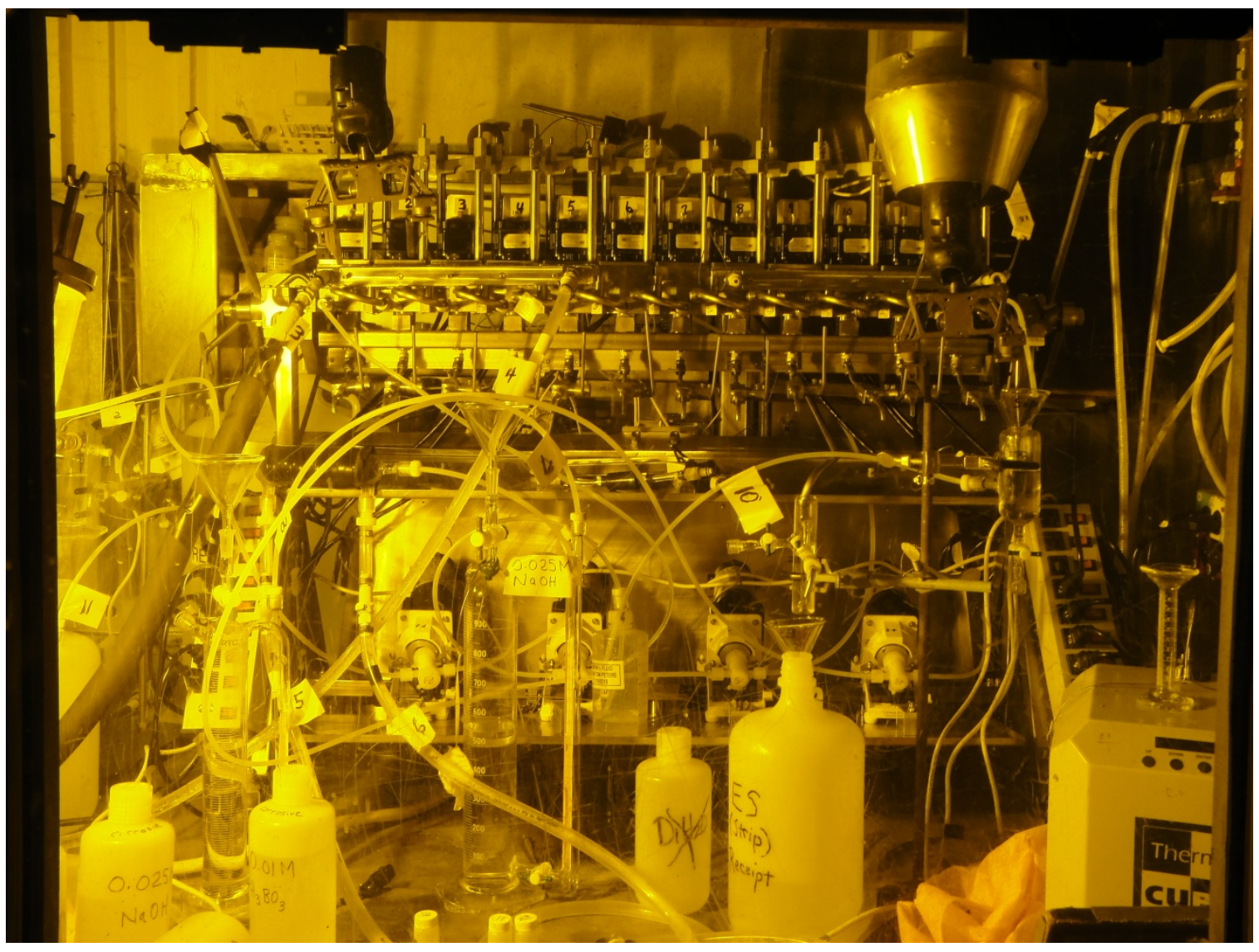

Figure 3-3. Contactor Apparatus in SRNL Shielded Cells Facility

\subsection{Contactor Operations}

Researchers operated the solvent extraction contactor apparatus in the following manner. To initiate an experiment, the contactor rotors were started and the scrub and strip stages were filled with scrub $(0.025 \mathrm{M} \mathrm{NaOH})$ and strip $\left(0.01 \mathrm{M} \mathrm{H}_{3} \mathrm{BO}_{3}\right)$ solutions. With the scrub and strip feeds running, startup simulant flow was initiated into the extraction bank at Stage 5. The startup simulant was a Tank $49 \mathrm{H}$ simulant solution containing no cesium. After achieving steady aqueous flow through the extraction stages (Stages 1 to 5), the solvent feed to Stage 1 was initiated. When solvent was observed exiting the final strip stage (Stage 12) the aqueous feed was switched from the startup simulant solution to the test solution (containing cesium).

During tests, researchers monitored the test apparatus for the following parameters. Monitoring intervals are indicated in parentheses.

- Rotation of all motors (15 min)

- Liquid level in standpipes (15 min) [non-radioactive test only]

- Feed tank levels (30 min). Tanks were filled as required.

- Decanter levels and solution clarity (15 min)

- Stage temperatures (15 min)

- Flow rate measurements and calculations (30 min) 
Samples were taken by placing sample containers at the outlet points of the continuously-flowing streams. The three sample locations were: 1 ) decontaminated salt solution (DSS) exiting the DSS decanter at the aqueous outlet from Stage 1, 2) strip effluent (SE) exiting the strip decanter at aqueous outlet from Stage 8, and 3) solvent outlet from Stage 12 prior to the solvent decanter.

At the end of each test, the motor rotation and feed pumps were stopped as quickly as possible to minimize disruption of the contents of each stage for the post-test stage samples. Stage samples were obtained by draining each stage into polypropylene bottles.

Following each test, the equipment was rinsed. The extraction and scrub stages were rinsed with $0.025 \mathrm{M} \mathrm{NaOH}$ solution to prevent precipitation of aluminum hydroxide in the waste. The Strip stages were rinsed with $0.01 \mathrm{M} \mathrm{H}_{3} \mathrm{BO}_{3}$. After flushing with $\mathrm{NaOH}$ or $\mathrm{H}_{3} \mathrm{BO}_{3}$, all stages were flushed with water.

\subsection{Sampling and Analysis}

Two contactor tests occurred with similar objectives and sampling plans. Appendix A details the Tank $49 \mathrm{H}$ salt simulant preparation; a sample was analyzed prior to the test. A data-collection sheet containing sample identification, sampling locations, and timing was prepared as described in the test method.

For the non-radioactive tests, samples were collected directly into glass vials with Teflon $^{\mathrm{TM}}$-lined screw-on caps. For the radioactive tests, strip solution and solvent samples were also collected directly into glass vials with Teflon ${ }^{\mathrm{TM}}$-lined caps; decontaminated salt solution samples were collected in polyethylene bottles and later a subset of the collected volume was transferred to glass vials with Teflon ${ }^{\mathrm{TM}}$-lined caps. The following summarizes the analytical methods that supported each objective.

\subsubsection{Stage Efficiency}

At the end of each test, researchers drained the contents of each stage into polypropylene bottles. All stage samples were transferred to glass separatory funnels. For the non-radioactive test, extraction and scrub Stages 1-7 were placed in a shaker bath at $23{ }^{\circ} \mathrm{C}$, shaken for several minutes, and then allowed to separate for approximately 24 hours; strip Stages 8-12 were placed in a shaker bath at $33^{\circ} \mathrm{C}$, shaken for several minutes, and then allowed to separate for approximately 24 hours. The final temperatures were measured and portions of each phase were analyzed for Cs. For the radioactive test, a similar protocol was followed except that all 12 stages were shaken at ambient temperature (which was $28.6^{\circ} \mathrm{C}$ ) and allowed to separate at ambient temperature. For non-radioactive solutions, ICPMS was used for analyses. For radioactive solutions, gamma spectroscopy was used to analyze the ${ }^{137} \mathrm{Cs}$ concentration.

Non-radioactive solvent samples were digested $\left(0.1 \mathrm{~mL}\right.$ sample in $3 \mathrm{~mL}$ concentrated $\left.\mathrm{HNO}_{3}\right)$ by heating at $165{ }^{\circ} \mathrm{C}$ for 2 hours in new Teflon ${ }^{\mathrm{TM}}$ pressure vessels. Each digested sample was diluted to $10 \mathrm{~mL}$ with water prior to analysis. For the radioactive waste tests, ${ }^{137} \mathrm{Cs}$ was counted by gamma ray spectroscopic techniques. For low activity samples $\left(<1 \times 10^{8} \mathrm{~d} / \mathrm{m} / \mathrm{mL}\right)$, portions were removed from the shielded cell and counted using Analytical Development (AD) routine methods. The AD method counts $3 \mathrm{~mL}$ of sample for 1000 seconds using an intrinsic germanium solid state detector. For moderate activity aqueous samples $\left(10^{8}\right.$ to $\left.10^{9} \mathrm{~d} / \mathrm{m} / \mathrm{mL}\right)$, aliquots were diluted by a factor of 20 with $0.01 \mathrm{M} \mathrm{H}_{3} \mathrm{BO}_{3}$ in the shielded cell, and a portion removed for gamma counting. 


\subsubsection{Decontamination and Concentration Factors}

During each test, researchers obtained samples of the three process streams (i.e., decontaminated salt solution, strip effluent, and stripped solvent) at intervals of 0.5-1.0 hours. Non-radioactive samples were analyzed for cesium by ICPMS and radioactive samples were analyzed by ${ }^{137} \mathrm{Cs}$ gamma counting techniques.

\subsubsection{Solvent Entrainment and Degradation}

Solvent or aqueous entrainment was measured primarily by the decanters. In addition, periodic samples of the effluent from the decanters were analyzed for modifier and MaxCalix by high performance liquid chromatography (HPLC), volatile organic analysis (VOA), semi-volatile organic analysis (SVOA), and Fourier Transform Infrared (FTIR) spectroscopy. Due to the high ${ }^{137} \mathrm{Cs}$ activity of the strip effluent samples in the radioactive waste test, they were extracted with dichloromethane ( $\sim 5 \mathrm{~mL}$ of dichloromethane to $3400 \mathrm{~mL}$ of sample) in the Shielded Cells and the extract removed for analysis. The entire contents of the SE receipt vessel were contacted with dichloromethane two consecutive times. Solvent composition was measured on solvent samples taken at the beginning and the end of the tests. Modifier and MaxCalix concentrations were measured by HPLC, VOA, SVOA, and FTIR.

\subsubsection{Minor Components}

Minor inorganic components in the aqueous and organic streams were measured by inductively coupled plasma emission spectroscopy (ICPES) and ICPMS for the non-radioactive test. Organic samples were first digested prior to analyses. Analyses were completed for the non-radioactive test every six hours on the decontaminated salt solution, strip effluent, and recycle solvent. Analyses of the minor inorganic components were also completed for the aqueous and organic samples taken from the stages at the end of the test.

For the radioactive test, the decontaminated salt solution and strip effluent were analyzed by ICPES at 12 and $24 \mathrm{~h}$. At the end of the test, a sample of the solvent reservoir was digested and analyzed using ICPES and ICPMS.

\subsection{Results and Discussion}

\subsection{ESS Test Results}

Table 4-1 shows the results from the Tank $49 \mathrm{H}$ waste and waste simulant ESS tests, corrected to the normal process operating temperatures $\left(23{ }^{\circ} \mathrm{C}\right.$ for extraction and $33{ }^{\circ} \mathrm{C}$ for scrubbing and stripping). ${ }^{[10]}$ Table 4-1 also includes reference $\mathrm{D}(\mathrm{Cs})$ values for the MaxCalix solvent system. ${ }^{[10]}$ The reference values serve as a point of comparison. However, when $\mathrm{D}(\mathrm{Cs})$ values do not meet the reference values, it does not necessarily indicate that a process upset has occurred, but should serve as an increased scrutiny of the result and the conditions contributing to the result.

Table 4-1. Cesium Distribution Ratios for the ESS Tests

\begin{tabular}{|c|c|c|c|c|c|c|}
\hline Material & Extract & Scrub \#1 & Scrub \#2 & Strip \#1 & Strip \#2 & Strip \#3 \\
\hline $\begin{array}{c}\text { NGCS, Tank 49H } \\
\text { simulant }\end{array}$ & 81 & 3.6 & 1.1 & 0.0095 & 0.0024 & 0.34 \\
\hline NGCS, Tank 49H waste & 88 & 5.0 & 3.0 & 0.0042 & 0.0047 & 0.0094 \\
\hline $\begin{array}{c}\text { Reference, MaxCalix } \\
\text { solvent system }\end{array}$ & $\sim 60$ & $\sim 2-4$ & $\sim 1-2.5$ & $\sim 0.33$ & $\sim 0.0007$ & $\sim 0.0003$ \\
\hline
\end{tabular}


For the ESS tests, the data for the simulant and Tank $49 \mathrm{H}$ waste tests show comparable results with the exception of Strip \#3. In this case, the poorer detection limit of the analytical method used in the cold simulant test is the cause of the apparent poorer result.

\subsection{Non-Radioactive Simulant Testing with Centrifugal Contactors}

Hydraulic performance verification tests were conducted in a non-radioactive laboratory (773-A, C151) with Tank $49 \mathrm{H}$ simulated waste containing non-radioactive cesium. The objective of the tests was to verify that the system performed as designed. One 24-h test was performed. In the test, approximately 34.5 liters of Cs-containing simulated waste was processed through the system. The feed rate setpoints and the observed feed rates as determined by volume measurements in graduated cylinders are included in Table 4-2. The test was completed without interruption. No temperature or flow rate issues were noted.

Table 4-2. Feed Rate Setpoints and Observed Flowrates for Non-Radioactive Test

\begin{tabular}{|l|l|l|}
\hline PROCESS FEED & FLOW SETPOINT & $\begin{array}{l}\text { OBSERVED } \\
\text { AVG. FLOW }\end{array}$ \\
\hline Waste Simulant & $24.0 \mathrm{~mL} / \mathrm{min}$ & $23.5 \mathrm{~mL} / \mathrm{min}$ \\
Solvent & $6.0 \mathrm{~mL} / \mathrm{min}$ & $6.1 \mathrm{~mL} / \mathrm{min}$ \\
Strip & $1.6 \mathrm{~mL} / \mathrm{min}$ & $1.6 \mathrm{~mL} / \mathrm{min}$ \\
Scrub & $1.6 \mathrm{~mL} / \mathrm{min}$ & $1.6 \mathrm{~mL} / \mathrm{min}$ \\
\hline
\end{tabular}

\subsubsection{Waste Decontamination}

Due to analytical limits for detecting non-radioactive cesium, the maximum measurable DF for the extraction section was approximately 6.6E+03 (see Table 4-3). Many of the hourly samples showed a DF greater than 6.6E+03 (red symbols in Figure 4-1), with an average DF of $>5.9 \mathrm{E}+03$. The data show a gradual decrease in DF from $>6.6 \mathrm{E}+03$ at $5 \mathrm{~h}$ to $3.9 \mathrm{E}+03$ at $12 \mathrm{~h}$ with full recovery to $>6.6 \mathrm{E}+03$ at $13 \mathrm{~h}$ (see Figure $4-1$ ). The test log provides no indication for the gradual loss of DF or its recovery.

The data were used with $\mathrm{D}(\mathrm{Cs})$ values reported later (see Section 4.2.5) to calculate stage efficiencies using the SASSE (Spreadsheet Algorithm for Stagewise Solvent Extraction) modeling program developed at ANL. ${ }^{[9]}$ The calculations showed that the stage efficiencies ranged from $89 \%$ to $91 \%$. 
Table 4-3. DSS Data for Non-Radioactive Simulant Test

\begin{tabular}{|c|c|c|c|c|c|}
\hline Feed Cs = & \multicolumn{2}{|c|}{$8.31 \mathrm{E}+04 \quad \mathrm{ug} / \mathrm{L}$} & & \multirow[b]{2}{*}{ Cs-133 } & \multirow[b]{3}{*}{ DF } \\
\hline & Cs-133 & & & & \\
\hline Time (h) & ug/L & DF & Time (h) & ug/L & \\
\hline $\mathbf{0}$ & $<12.5$ & & 12 & 21.1 & $3.9 E+03$ \\
\hline 0.5 & $<12.5$ & $>6.6 \mathrm{E}+03$ & 13 & $<12.5$ & $>6.6 \mathrm{E}+03$ \\
\hline 1 & $<12.5$ & $>6.6 \mathrm{E}+03$ & 14 & 13.6 & $6.1 \mathrm{E}+03$ \\
\hline 1.5 & $<12.5$ & $>6.6 \mathrm{E}+03$ & 15 & $<12.5$ & $>6.6 \mathrm{E}+03$ \\
\hline 2 & $<12.5$ & $>6.6 \mathrm{E}+03$ & 16 & $<12.5$ & $>6.6 \mathrm{E}+03$ \\
\hline 3 & 13.0 & $6.4 \mathrm{E}+03$ & 17 & $<12.5$ & $>6.6 \mathrm{E}+03$ \\
\hline 4 & $<12.5$ & $>6.6 \mathrm{E}+03$ & 18 & \multicolumn{2}{|c|}{ Compromised } \\
\hline 5 & $<12.5$ & $>6.6 \mathrm{E}+03$ & 19 & $<12.5$ & $>6.6 \mathrm{E}+03$ \\
\hline 6 & 14.7 & $5.6 \mathrm{E}+03$ & 20 & 16.3 & $5.1 \mathrm{E}+03$ \\
\hline 7 & 16.6 & $5.0 \mathrm{E}+03$ & 21 & 13.7 & $6.2 \mathrm{E}+03$ \\
\hline 8 & 17.0 & $4.9 \mathrm{E}+03$ & 22 & $<12.5$ & $>6.6 \mathrm{E}+03$ \\
\hline 9 & 18.3 & $4.5 \mathrm{E}+03$ & 23 & 13.5 & $6.2 \mathrm{E}+03$ \\
\hline 10 & 18.4 & $4.5 \mathrm{E}+03$ & 24 & 13.0 & $6.4 \mathrm{E}+03$ \\
\hline 11 & 20.0 & 4.2E+03 & & & \\
\hline
\end{tabular}

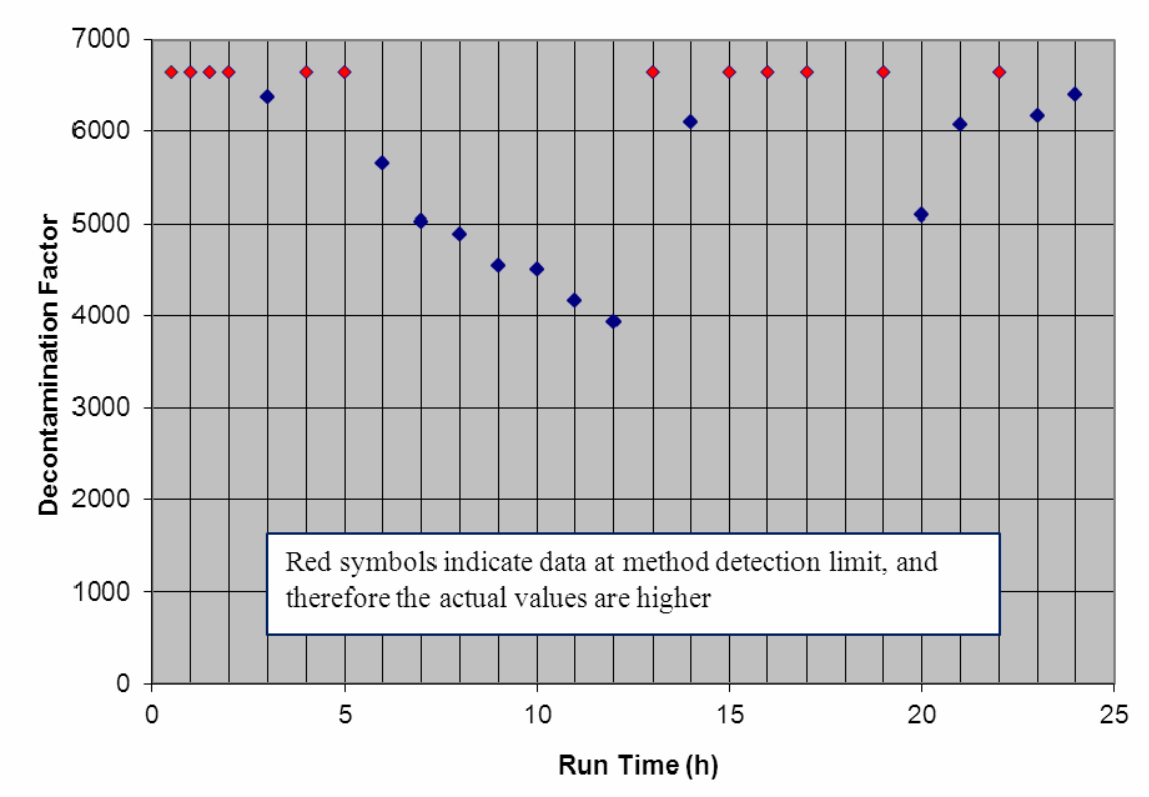

Figure 4-1. Decontamination Factors for the Non-Radioactive Test

\subsubsection{Concentration Factors}

The concentration factors (CF) for the test were consistent from the moment steady state is achieved (at $\sim 2 \mathrm{~h}$ ) until completion of the test (Table 4-4). The average CF for the test based on the waste feed and strip feed flow rates (Table 4-2) was 14.7. There appears to be a bi-modal distribution in the SE data with the CF ranging from 11.4 to 12.7 (average $=12.1 \pm 2.4$ ) during the 
first half of the test $(2-12 \mathrm{~h}$ ) and ranging from 12.8 to 13.5 (average $=13.1 \pm 2.6$ ) for the second half of the test (13-24 h). The likely shift at $12 \mathrm{~h}$ can be attributed to analytical uncertainty for ICPMS (uncertainty $=20 \%$ ). The samples for the first half of the test were analyzed on a different day than those from the second half of the test. The shift is not likely related to the shift in DF discussed in Section 4.2.1.

Table 4-4. SE Data for Non-Radioactive Simulant Test

\begin{tabular}{|c|c|c|c|c|c|}
\hline \multirow[t]{2}{*}{ Feed Cs $=$} & \multicolumn{2}{|c|}{$8.3 \mathrm{E}+04 \quad \mathrm{ug} / \mathrm{L}$} & & \multirow[b]{2}{*}{ Cs-133 } & \multirow[b]{3}{*}{ CF } \\
\hline & Cs-133 & & & & \\
\hline Time (h) & ug/L & CF & Time (h) & ug/L & \\
\hline $\mathbf{0}$ & $1.93 \mathrm{E}+02$ & & 12 & $9.76 \mathrm{E}+05$ & 11.7 \\
\hline 0.5 & $2.52 \mathrm{E}+05$ & 3.0 & 13 & $1.10 \mathrm{E}+06$ & 13.2 \\
\hline 1 & $7.06 \mathrm{E}+05$ & 8.5 & 14 & $1.06 \mathrm{E}+06$ & 12.8 \\
\hline 1.5 & $9.00 \mathrm{E}+05$ & 10.8 & 15 & $1.10 \mathrm{E}+06$ & 13.3 \\
\hline 2 & $1.06 \mathrm{E}+06$ & 12.7 & 16 & $1.11 \mathrm{E}+06$ & 13.3 \\
\hline 3 & $1.02 \mathrm{E}+06$ & 12.3 & 17 & $1.09 \mathrm{E}+06$ & 13.1 \\
\hline 4 & $1.04 \mathrm{E}+06$ & 12.5 & 18 & $1.09 \mathrm{E}+06$ & 13.1 \\
\hline 5 & $1.05 \mathrm{E}+06$ & 12.7 & 19 & $1.11 \mathrm{E}+06$ & 13.3 \\
\hline 6 & $9.78 \mathrm{E}+05$ & 11.8 & 20 & $1.10 \mathrm{E}+06$ & 13.2 \\
\hline 7 & $9.47 \mathrm{E}+05$ & 11.4 & 21 & $1.07 \mathrm{E}+06$ & 12.8 \\
\hline 8 & $9.55 \mathrm{E}+05$ & 11.5 & 22 & $1.10 \mathrm{E}+06$ & 13.2 \\
\hline 9 & $9.87 E+05$ & 11.9 & 23 & $1.07 \mathrm{E}+06$ & 12.9 \\
\hline 10 & $1.00 \mathrm{E}+06$ & 12.0 & 24 & $1.12 \mathrm{E}+06$ & 13.5 \\
\hline 11 & $1.02 \mathrm{E}+06$ & 12.3 & & & \\
\hline
\end{tabular}

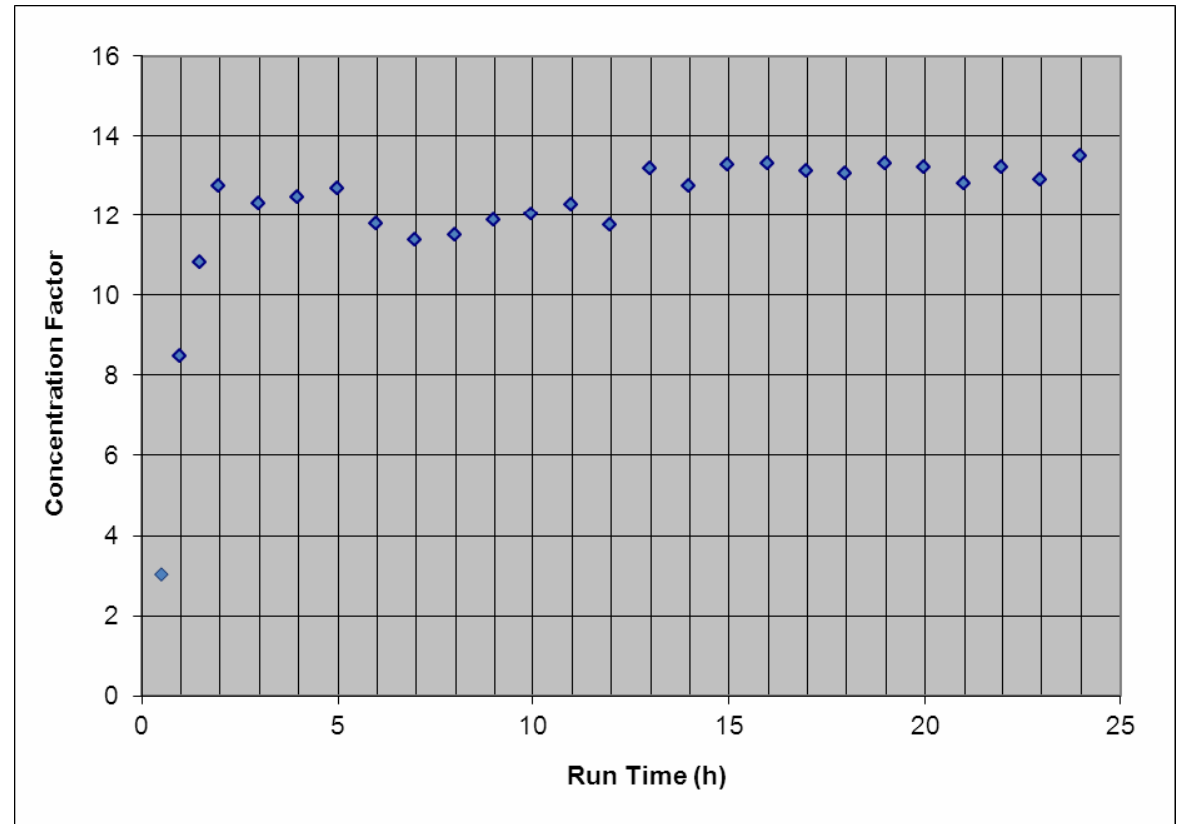

Figure 4-2. Concentration Factors for the Non-Radioactive Simulant Test 


\subsubsection{Distribution of Inorganic Components}

The quantities of inorganic components were measured every six hours for the DSS, SE, and solvent streams using ICPES. The data are provided in Table 4-5 for those components that produced a measurable response. Of particular interest are those components that are known to compete with $\mathrm{Cs}$, such as sodium ( $\mathrm{Na}$ ) and potassium (K). The data show that both $\mathrm{Na}$ and $\mathrm{K}$ were at measurable concentrations in the strip effluent but below the detection limit in the solvent. The presence of $\mathrm{K}$ and $\mathrm{Na}$ in strip samples is an indicator of incomplete scrubbing. Although the detection limits for $\mathrm{Na}$ and $\mathrm{K}$ in the solvent are fairly high, the data indicates that $\mathrm{Na}$ and $\mathrm{K}$ that are either entrained in or bound to the solvent are removed by the strip solution.

Both silicon ( $\mathrm{Si}$ ), probably as silicate, and sulfur (S), probably as sulfate, have measurable quantities consistently in the solvent. Furthermore, there are no measurable concentrations of $S$ in the strip effluent, and the concentration of $\mathrm{Si}$ in the strip effluent is much lower than the concentration in the solvent. This indicates that silicate and sulfate react with the solvent and are not readily removed by the $0.01 \mathrm{M} \mathrm{H}_{3} \mathrm{BO}_{3}$. The concentration of sulfur in the solvent may not have reached a steady value during the test. The presence of copper $(\mathrm{Cu})$, iron $(\mathrm{Fe})$, and nickel (Ni) in the solvent stream is interesting because none of those components were included in the feed material. They are likely the result of impurities in the line at other locations in the system. 
Table 4-5. Distribution of Inorganic Components (in $\mathrm{mg} / \mathrm{L}$ ) as a Function of Time

\begin{tabular}{|c|c|c|c|c|c|c|c|c|}
\hline ELEMENT & Sample & Start & $0.5 \mathrm{~h}$ & $6 \mathrm{~h}$ & $12 \mathrm{~h}$ & $18 \mathrm{~h}$ & $24 \mathrm{~h}$ & Avg \\
\hline \multirow[t]{3}{*}{$\mathrm{Al}$} & DSS & 4780 & 4790 & 4770 & 4750 & $\mathrm{n} / \mathrm{a}$ & 4660 & 4700 \\
\hline & $\mathrm{SE}$ & $<0.245$ & $<0.245$ & 0.69 & 0.78 & 1.33 & 0.928 & 0.786 \\
\hline & ORG & $\mathrm{n} / \mathrm{a}$ & 8.29 & $<7.49$ & 13.4 & 16.5 & $<7.49$ & $\mathrm{n} / \mathrm{a}$ \\
\hline \multirow[t]{3}{*}{$\mathrm{B}$} & DSS & $<2.68$ & $<2.68$ & $<2.68$ & $<2.68$ & $\mathrm{n} / \mathrm{a}$ & 3.2 & 2.9 \\
\hline & SE & 105 & 104 & 106 & 107 & 103 & 105 & 106 \\
\hline & ORG & $\mathrm{n} / \mathrm{a}$ & $<3.49$ & $<3.68$ & $<3.45$ & $<3.56$ & $<3.68$ & $\mathrm{n} / \mathrm{a}$ \\
\hline \multirow[t]{3}{*}{$\mathrm{Ca}$} & DSS & $<3.15$ & $<3.15$ & $<3.15$ & $<3.15$ & $\mathrm{n} / \mathrm{a}$ & $<3.29$ & $<3.29$ \\
\hline & $\mathrm{SE}$ & 0.47 & 0.58 & 0.35 & 0.38 & $<0.66$ & $<0.66$ & $<0.66$ \\
\hline & ORG & $\mathrm{n} / \mathrm{a}$ & 11 & 11.7 & 58.7 & 34.8 & 17.2 & $\mathrm{n} / \mathrm{a}$ \\
\hline \multirow[t]{3}{*}{ Cs } & DSS & $<0.012$ & $<0.0125$ & 0.0147 & 0.0211 & $\mathrm{n} / \mathrm{a}$ & 0.0130 & $<0.0125$ \\
\hline & $\mathrm{SE}$ & 0.19 & 252 & 978 & 976 & 1090 & 1120 & 1010 \\
\hline & ORG & $\mathrm{n} / \mathrm{a}$ & 0.00374 & 0.00344 & 0.00905 & 0.00696 & 0.0069 & $\mathrm{n} / \mathrm{a}$ \\
\hline \multirow[t]{3}{*}{$\mathrm{Cu}$} & DSS & $<0.36$ & $<0.36$ & $<0.36$ & $<0.36$ & $\mathrm{n} / \mathrm{a}$ & $<0.98$ & $<0.98$ \\
\hline & $\mathrm{SE}$ & $<0.098$ & $<0.098$ & $<0.098$ & $<0.098$ & $<0.196$ & $<0.196$ & $<0.196$ \\
\hline & ORG & $\mathrm{n} / \mathrm{a}$ & 23.6 & 10.2 & 37.2 & $<2.7$ & 3.21 & $\mathrm{n} / \mathrm{a}$ \\
\hline \multirow[t]{3}{*}{$\mathrm{Fe}$} & DSS & $<1$ & 1.3 & $<1$ & 1.3 & $\mathrm{n} / \mathrm{a}$ & $<1.14$ & $<1.14$ \\
\hline & $\mathrm{SE}$ & $<0.114$ & $<0.114$ & $<0.114$ & $<0.114$ & $<0.19$ & $<0.19$ & $<0.19$ \\
\hline & ORG & $\mathrm{n} / \mathrm{a}$ & 9.48 & 4.58 & 14.7 & 7.12 & 8.48 & $\mathrm{n} / \mathrm{a}$ \\
\hline \multirow[t]{3}{*}{$\mathrm{K}$} & DSS & 491 & 484 & 483 & 477 & $\mathrm{n} / \mathrm{a}$ & 476 & 476 \\
\hline & SE & 9.78 & 19.9 & 23.3 & 24.5 & 24.1 & 29.8 & 23.8 \\
\hline & ORG & $\mathrm{n} / \mathrm{a}$ & $<31.7$ & $<33.4$ & $<31.3$ & $<32.3$ & $<33.4$ & $\mathrm{n} / \mathrm{a}$ \\
\hline \multirow[t]{3}{*}{$\mathrm{Na}$} & DSS & 140000 & 139000 & 134000 & 142000 & $\mathrm{n} / \mathrm{a}$ & 138000 & 138000 \\
\hline & $\mathrm{SE}$ & 15.8 & 71.3 & 180 & 164 & 150 & 161 & 160 \\
\hline & ORG & $\mathrm{n} / \mathrm{a}$ & $<11.0$ & $<11.5$ & $<10.8$ & 18.5 & $<11.5$ & $\mathrm{n} / \mathrm{a}$ \\
\hline \multirow[t]{3}{*}{$\mathrm{Ni}$} & DSS & $<0.43$ & $<0.43$ & $<0.43$ & $<0.43$ & $\mathrm{n} / \mathrm{a}$ & $<0.43$ & $<0.43$ \\
\hline & $\mathrm{SE}$ & $<0.043$ & $<0.043$ & $<0.043$ & $<0.043$ & $<0.088$ & $<0.088$ & $<0.088$ \\
\hline & ORG & $\mathrm{n} / \mathrm{a}$ & 8.93 & 4.5 & 22.6 & 3.55 & 2.4 & $\mathrm{n} / \mathrm{a}$ \\
\hline \multirow[t]{3}{*}{$\mathrm{P}$} & DSS & 98.7 & 101 & 95.3 & 98.1 & $\mathrm{n} / \mathrm{a}$ & 97.1 & 96.9 \\
\hline & $\mathrm{SE}$ & $<0.48$ & $<0.48$ & $<0.48$ & $<0.48$ & $<0.37$ & $<0.37$ & $<0.37$ \\
\hline & ORG & $\mathrm{n} / \mathrm{a}$ & $<6.3$ & $<6.6$ & $<6.2$ & $<6.4$ & $<6.6$ & $\mathrm{n} / \mathrm{a}$ \\
\hline \multirow[t]{3}{*}{$S$} & DSS & 1740 & 1750 & 1730 & 1720 & $\mathrm{n} / \mathrm{a}$ & 1680 & 1720 \\
\hline & $\mathrm{SE}$ & $<0.735$ & $<0.735$ & $<0.735$ & $<0.735$ & $<1.47$ & $<1.47$ & $<1.4$ \\
\hline & ORG & $\mathrm{n} / \mathrm{a}$ & 13.4 & 19.3 & 27.1 & 36.7 & 42.1 & $\mathrm{n} / \mathrm{a}$ \\
\hline \multirow[t]{3}{*}{$\mathrm{Si}$} & DSS & 111 & 128 & 138 & 151 & $\mathrm{n} / \mathrm{a}$ & 121 & 137 \\
\hline & $\mathrm{SE}$ & 2.75 & 4.27 & 2.82 & 3.35 & & 2.88 & 2.22 \\
\hline & ORG & $\mathrm{n} / \mathrm{a}$ & 22.7 & 48.9 & 54.8 & 67.8 & 30.3 & $\mathrm{n} / \mathrm{a}$ \\
\hline \multirow[t]{3}{*}{$\mathrm{Zn}$} & DSS & 1.3 & 1.4 & 1.2 & 1.3 & $\mathrm{n} / \mathrm{a}$ & 1.4 & 1.4 \\
\hline & $\mathrm{SE}$ & $<0.083$ & $<0.083$ & $<0.083$ & $<0.083$ & $<0.18$ & $<0.18$ & $<0.18$ \\
\hline & ORG & $\mathrm{n} / \mathrm{a}$ & $<1.17$ & $<1.2$ & 1.52 & $<1.2$ & $<1.2$ & $\mathrm{n} / \mathrm{a}$ \\
\hline \multicolumn{9}{|c|}{$\mathrm{n} / \mathrm{a}=$ no sample collected or sample compromised } \\
\hline \multicolumn{9}{|c|}{ Cs measurement uncertainty $=20 \%$} \\
\hline \multicolumn{5}{|c|}{ Measurement uncertainty for all other analytes $=10 \%$} & & & & \\
\hline
\end{tabular}

\subsubsection{Second-Phase Carryover}

Second-phase carryover was determined by two methods: 1) volumetric measurement of secondphases in decanters, and 2) VOA and SVOA analyses of effluent streams. Pictures of the effluent streams, as collected in the three outlet decanters near the end of the test, are provided in Figure 4-3. The SE was quite clear, but was found to contain $1.3 \mathrm{~mL}$ of organic carry over. The 
DSS contained no (volumetrically) measurable second-phase carry over, but the overall solution was cloudy. The solvent recycle stream was clear and contained no discernible second-phase.

At 8, 16, and $24 \mathrm{~h}, 25-\mathrm{mL}$ DSS samples were collected and submitted for organic analyses by VOA and SVOA. Similarly, at the end of the test, the entire SE solution $(\sim 2.4 \mathrm{~L})$ was submitted in three separate aliquots (0-8 h, 8-16 h, and 16-24 h) for VOA and SVOA analyses. For the DSS and SE samples, the aqueous sample was contacted with hexane to extract the organics from the aqueous sample into the hexane, and then the hexane was analyzed. The data are listed in Table 4-6. Only the 16-h DSS sample contained any measurable amount of solvent. However, the presence of modifier without Isopar ${ }^{\circledR}$ L suggests an erroneous result.
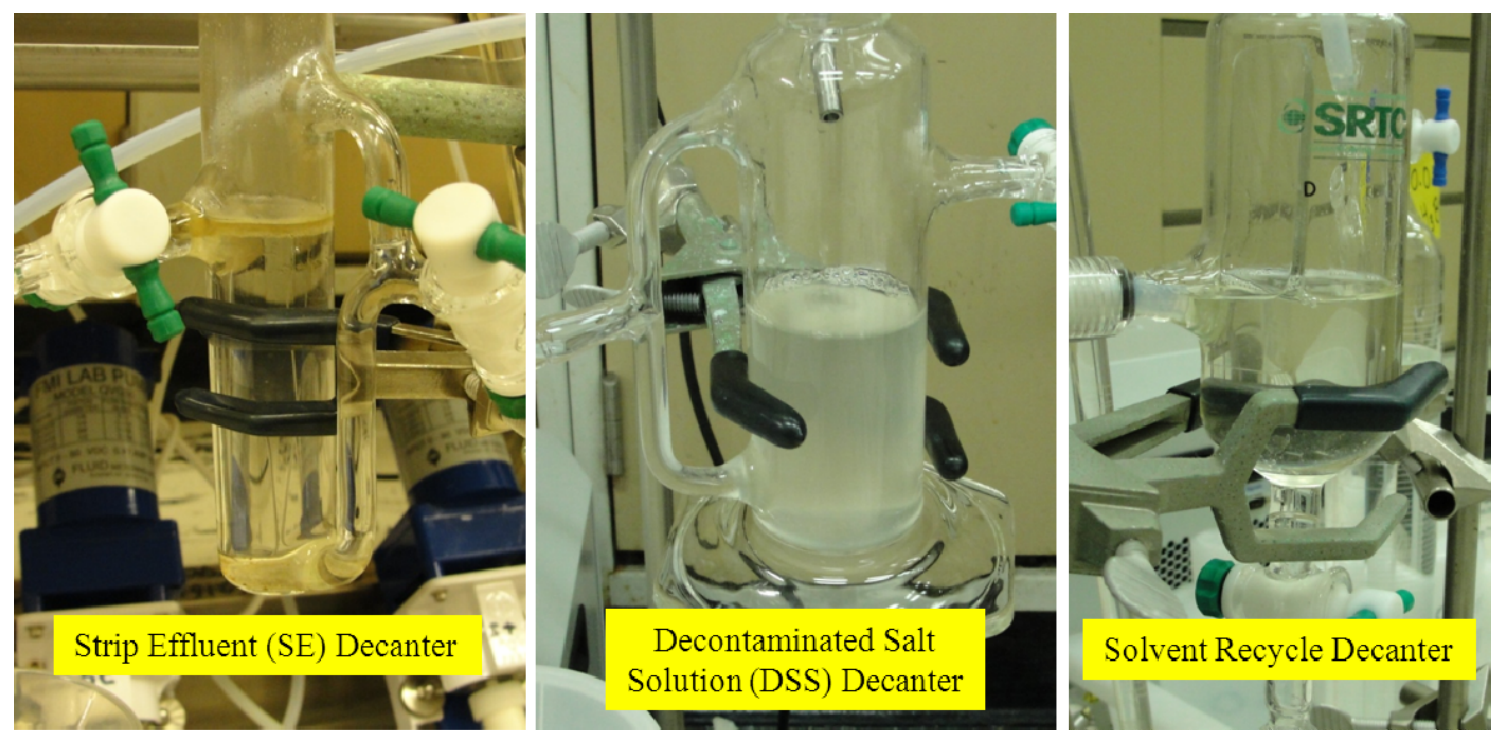

Figure 4-3. Outlet Stream Decanters Depicting Second-Phase Carryover

Table 4-6. Simulant Test Organic Carry Over into the DSS and SE Streams

\begin{tabular}{|c|c|c|c|c|}
\hline \multirow{2}{*}{ Sample } & VOA (mg/L) & \multicolumn{3}{|c|}{ SVOA (mg/L) } \\
\cline { 2 - 5 } & All Analytes & Isopar $^{\circledR} \mathrm{L}$ & Modifier & Other Analytes \\
\hline 8-h DSS & $<0.1$ & $<33$ & $<50$ & $<0.1$ \\
\hline 16-h DSS & $<0.1$ & $<33$ & 98 & $<0.1$ \\
\hline 24-h DSS & $<0.1$ & $<33$ & $<50$ & $<0.1$ \\
\hline & \multicolumn{3}{|c|}{} \\
\hline 8-h SE & $<0.1$ & $<10$ & $<10$ & $<0.1$ \\
\hline 16-h SE & $<0.1$ & $<10$ & $<10$ & $<0.1$ \\
\hline 24-h SE & $<0.1$ & $<10$ & $<10$ & $<0.1$ \\
\hline
\end{tabular}

Table 4-7. Non-Radioactive Simulant Test Second-Phase Carryover Rates

\begin{tabular}{|l|l|}
\hline DSS Decanter & $0 \mathrm{~mL}$ of second-phase carry over out of a total flow of 36,900 mL \\
\hline SE Decanter & $\begin{array}{l}1.3 \mathrm{~mL} \text { of second-phase carry over out of a total flow of } 2,300 \mathrm{~mL} \\
(0.056 \%)\end{array}$ \\
\hline $\begin{array}{l}\text { Solvent Recycle } \\
\text { Decanter }\end{array}$ & $0 \mathrm{~mL}$ of second-phase carry over out of a total flow of 8,640 mL \\
\hline
\end{tabular}




\subsubsection{Stage Data}

Cesium distribution ratios $[\mathrm{D}(\mathrm{Cs})]$ were measured for 11 of the 12 stages (Stage 7 was compromised during sample handling). Distribution ratios listed in Table 4-8 were measured on stage samples at $23{ }^{\circ} \mathrm{C}$ (Stages 1-6) and $33{ }^{\circ} \mathrm{C}$ (Stages 8-12) following the test. There was no need to perform a temperature correction of the $\mathrm{D}(\mathrm{Cs})$ values. ${ }^{[10]}$ The organic and aqueous concentrations are graphed in Figure 4-4.

Table 4-8. Equilibrium Distribution Ratios for Non-Radioactive Test

\begin{tabular}{|c|c|c|c|c|c|}
\hline Section & Stage & $\begin{array}{c}\text { Organic } \\
{ }^{133} \mathrm{Cs} \\
(\mu \mathrm{g} / \mathrm{L})\end{array}$ & $\begin{array}{c}\text { Aqueous } \\
{ }_{133} \mathrm{Cs} \\
(\mu \mathrm{g} / \mathrm{L})\end{array}$ & $\begin{array}{c}\text { Test } \\
\text { Temp } \\
\left({ }^{\circ} \mathrm{C}\right)\end{array}$ & $\mathrm{D}(\mathrm{Cs})$ \\
\hline Extraction & 1 & $1.30 \mathrm{E}+03$ & $2.40 \mathrm{E}+01$ & 23 & 54 \\
\hline Extraction & 2 & $1.33 \mathrm{E}+03$ & $1.78 \mathrm{E}+01$ & 23 & 75 \\
\hline Extraction & 3 & $2.26 \mathrm{E}+03$ & $3.16 \mathrm{E}+01$ & 23 & 72 \\
\hline Extraction & 4 & $6.47 \mathrm{E}+04$ & $2.33 \mathrm{E}+02$ & 23 & 278 \\
\hline Extraction & 5 & $2.69 \mathrm{E}+05$ & $3.25 E+03$ & 23 & 83 \\
\hline Scrub & 6 & $4.06 \mathrm{E}+05$ & $2.19 \mathrm{E}+05$ & 23 & 1.9 \\
\hline Scrub & 7 & \multicolumn{4}{|c|}{ Sample compromised } \\
\hline Strip & 8 & $1.62 \mathrm{E}+05$ & $1.14 \mathrm{E}+06$ & 33 & 0.14 \\
\hline Strip & 9 & $7.28 \mathrm{E}+04$ & $6.13 \mathrm{E}+05$ & 33 & 0.12 \\
\hline Strip & 10 & $7.71 \mathrm{E}+03$ & $2.74 \mathrm{E}+05$ & 33 & 0.028 \\
\hline Strip & 11 & $1.14 \mathrm{E}+03$ & $1.00 \mathrm{E}+05$ & 33 & 0.011 \\
\hline Strip & 12 & $1.71 \mathrm{E}+02$ & $1.28 \mathrm{E}+04$ & 33 & 0.013 \\
\hline
\end{tabular}




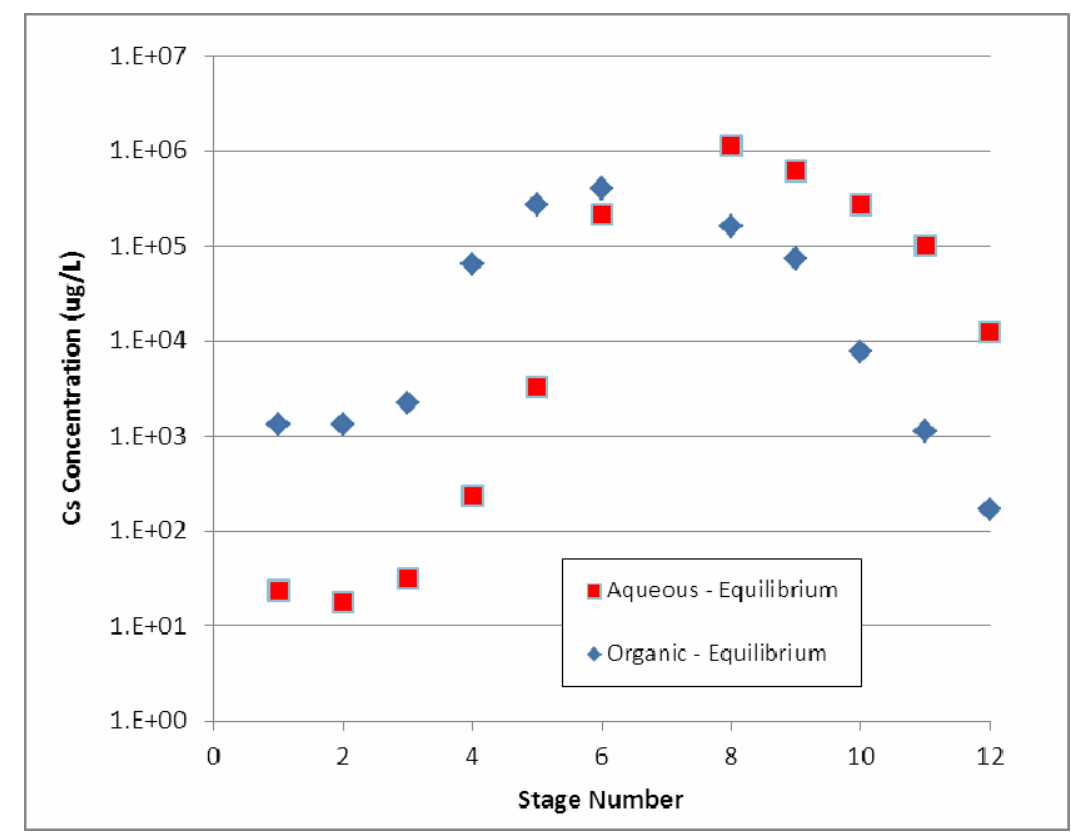

Figure 4-4. Stage Sample Data for the Non-Radioactive Simulant Test

In the initial analyses, problems were detected in the data for the organic in Stages 1-3 and 10-12. The samples were re-analyzed to yield the data in Table 4-8. In retrospect, the organic sample from Stage 4 should have also been analyzed as the $\mathrm{D}(\mathrm{Cs})$ value for Stage 4 appears to be in error. The distribution ratios in Stages 1-3 and 5 are in the acceptable range (Table 4-1), although a little lower than the ESS test values. Based on the ESS tests, the expected range for extraction $\mathrm{D}(\mathrm{Cs})$ values is $81-88$, for scrub $\mathrm{D}(\mathrm{Cs})$ values is $\sim 1.0-5.0$, and for strip $\mathrm{D}(\mathrm{Cs})$ values is $0.002-0.010$. The $\mathrm{D}(\mathrm{Cs})$ for scrub in Stage 6 is also in the expected range. The strip data for Stages 8-12 are higher than expected. The loss of the Stage 7 sample makes it difficult to determine if there were any issues associated with the scrub section that caused problems in stripping. As will be noted in Section 4.3.6, a possible issue with scrubbing was noted during the test with actual Tank $49 \mathrm{H}$ waste. The shape of the stage data shown in Figure 4-4 is consistent with what is expected. The shapes of the curves also closely resemble a plot of the data from the Tank $49 \mathrm{H}$ waste test (Figure 4-9).

Stage data were also collected for elements other than Cs. ICPES data for the aqueous and organic fractions of each stage after equilibration are provided in Appendix B. The data for the extraction section shows that the concentrations of components are largely unchanged in the bank except for the concentration of $\mathrm{Cs}$, which was reduced from $83.1 \mathrm{mg} / \mathrm{L}$ to $0.0316 \mathrm{mg} / \mathrm{L}$ in three extraction stages. The concentration of Cs for the final two extraction stages is relatively constant, possibly due to the presence of Cs in the solvent being fed to the extraction section in Stage 1 . The cause of Cs in the solvent may be attributable to inefficient scrubbing discussed above. Inefficient scrubbing would negatively affect the strip section, thus leading to Cs being retained in the solvent recycled to Stage 1.

The stage data show comparable behavior for Cs, $\mathrm{K}$, and $\mathrm{Na}$ in the strip section. For all three elements, the concentrations in the aqueous phase are highest in Stage 8 and decrease with each successive stage. The same is true for Cs in the organic phase, while the concentrations of $\mathrm{K}$ and $\mathrm{Na}$ are below the method detection limits. Conversely, Si and S exhibit relatively constant concentrations across the strip section, both in the aqueous and organic phases. This is further indication that perhaps silicate and sulfate have attached to the solvent and are not removed by 
either the scrub or the strip solutions. The source of calcium (Ca) in the system is unknown, but it is worth noting that in the extraction and stripping sections it has partitioned to the organic phase.

\subsubsection{Stage Temperatures}

The non-radioactive test was conducted in a laboratory with an ambient temperature of $21^{\circ} \mathrm{C}$ (compared to $30{ }^{\circ} \mathrm{C}$ for the real waste test). The temperatures in the extraction and scrub stages were actively controlled. Consequently, the temperatures were maintained within acceptable ranges. The aqueous flow out of Stage 1 (extraction) was controlled between 19.8 and $21.2{ }^{\circ} \mathrm{C}$ with an average of $20.6{ }^{\circ} \mathrm{C}$. The aqueous flow from Stage 3 to Stage 2 (extraction) was controlled between 21.0 and $22.1^{\circ} \mathrm{C}$ with an average of $21.6^{\circ} \mathrm{C}$. The organic flow from Stage 10 to Stage 11 (strip) was maintained between 27.9 and $30.7^{\circ} \mathrm{C}$ with an average of $29.4{ }^{\circ} \mathrm{C}$. The organic flow out of Stage 12 (strip) ranged from 28.2 to $31.2^{\circ} \mathrm{C}$ with an average of $30.0^{\circ} \mathrm{C}$. The Stage 6 (scrub) and Stage 7 (scrub) block temperatures operated at averages of 31.5 and $34.4{ }^{\circ} \mathrm{C}$, respectively.

\subsubsection{Solvent Degradation and Impurities}

Analyses of the solvent for degradation products are important because it has been demonstrated that degradation products can negatively affect solvent performance. ${ }^{[11]}$ ICPMS analysis of a solvent reservoir sample after the test showed that the solvent reservoir contained $6.88 \mu \mathrm{g} / \mathrm{L}$ Cs. Analyses of the solvent return samples (exiting Stage 12) contained an average Cs concentration of $9.29 \mu \mathrm{g} / \mathrm{L}$. Analyses of the solvent reservoir sample before (ORG_0) and after 20 solvent turnovers (ORG_24) using VOA, SVOA, HPLC, and FTIR are provided in Table 4-9 and Figure 4-5. A difference analysis of the two spectra (Figure 4-6 ) shows a trace peak at the C-H stretch at $2900 \mathrm{~cm}^{-1}$ which is likely from the different amounts of Isopar ${ }^{\circledR} \mathrm{L}$ on the analyzer crystal when the spectra were taken.

Table 4-9. Analyses of Solvent - Before and After Simulant Test (mg/L)

\begin{tabular}{|c|c|c|c|c|c|c|c|}
\hline \multirow[b]{2}{*}{ Sample } & \multirow{2}{*}{$\begin{array}{c}\text { VOA } \\
\text { All Analytes } \\
\end{array}$} & \multicolumn{3}{|c|}{ SVOA } & \multicolumn{2}{|c|}{ HPLC } & \multirow{2}{*}{$\begin{array}{l}\text { Density } \\
(\mathrm{g} / \mathrm{mL})\end{array}$} \\
\hline & & Isopar $^{(B)} \mathbf{L}$ & Modifier & Other & Modifier & Extractant & \\
\hline Org_0 & $<50,000$ & 600000 & 92000 & $<10000$ & 176000 & 45500 & 0.8262 \\
\hline Org_24 & $<50,000$ & 570000 & 87000 & $<10000$ & 184000 & 46200 & 0.8326 \\
\hline
\end{tabular}

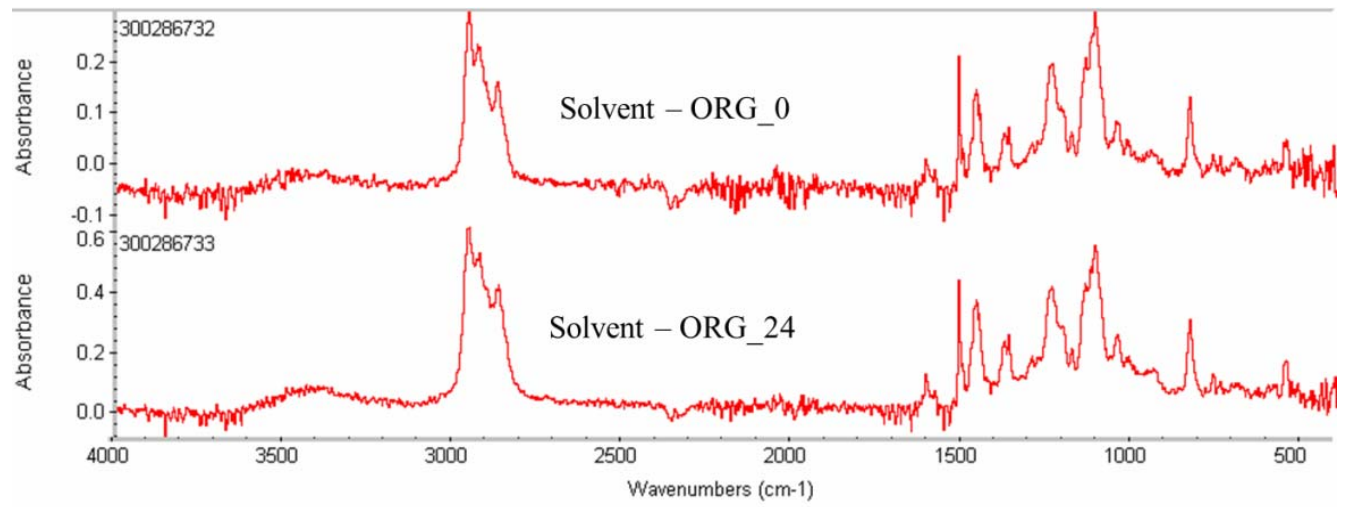

Figure 4-5. FTIR Analyses of Solvent from Simulant Test 


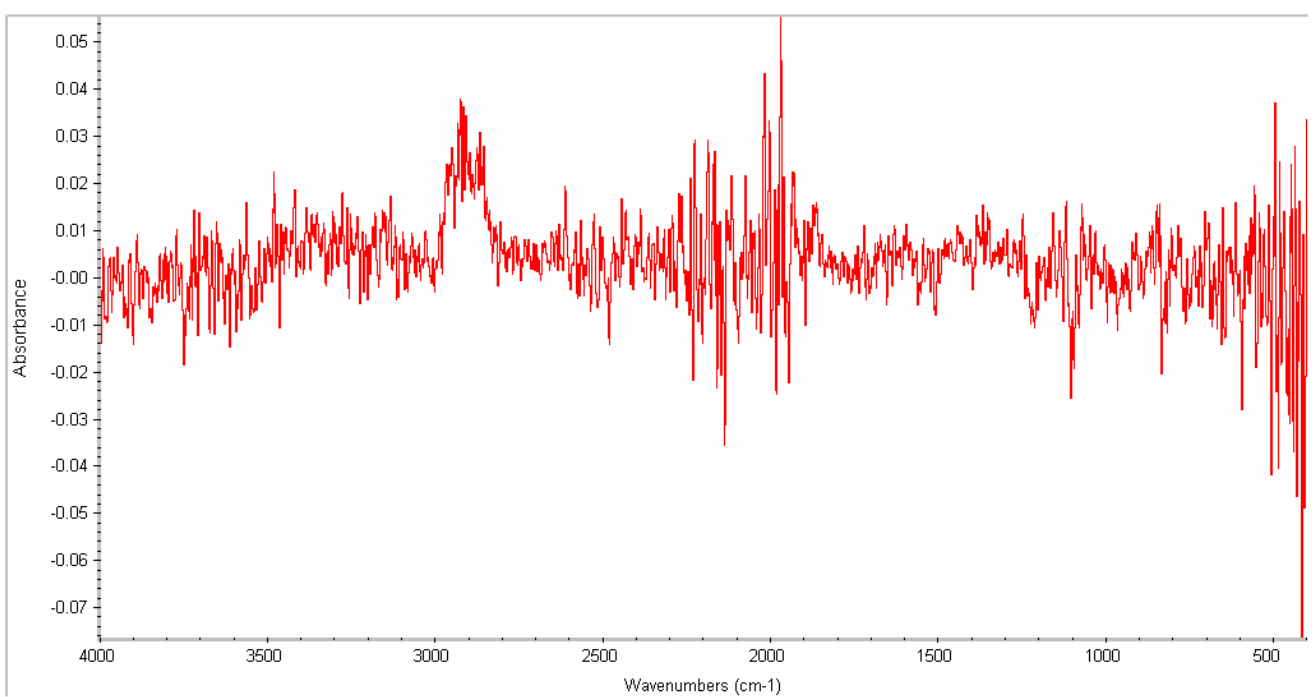

Figure 4-6. FTIR Spectra Difference Analysis of Solvent from Simulant Test

Within analytical uncertainty, there was no change in the composition of the solvent. However, the data suggests that Isopar ${ }^{\circledR} \mathrm{L}$ has evaporated. The concentration of Isopar ${ }^{\circledR} \mathrm{L}$ (measured by SVOA) decreased while the concentrations of modifier and extractant (measured by HPLC) increased. A similar behavior was observed for the Tank 49H HLW test (Table 4-18). It should be noted that SVOA measurements indicate that the modifier concentration decreased. However, HPLC, which has a lower measurement uncertainty than SVOA and is a better method for measuring modifier concentration, is considered the more-reliable result. The evaporation of Isopar ${ }^{\circledR} \mathrm{L}$ is consistent with MCU operating experience with BOBCalixC6.

\subsection{Tank 49H Real Waste Test with Centrifugal Contactors}

\subsubsection{Hydraulic Performance}

The test fed radioactive feed for $26.75 \mathrm{~h}$, and was completed without interruption. In the test, approximately 39 liters of Tank $49 \mathrm{H}$ waste solution was decontaminated in the system. The feed rate setpoints and the observed feed rates as determined by volume measurements in graduated cylinders are included in Table 4-10. No flow rate or bulk second-phase carry-over issues were noted.

Table 4-10. Feed Rate Setpoints and Observed Feed Rates for Tank 49H HLW Test

\begin{tabular}{|l|l|l|}
\hline $\begin{array}{l}\text { PROCESS } \\
\text { FEED }\end{array}$ & \multicolumn{1}{|c|}{$\begin{array}{c}\text { FLOW } \\
\text { SETPOINT }\end{array}$} & \multicolumn{1}{c|}{$\begin{array}{c}\text { OBSERVED } \\
\text { AVG. FLOW }\end{array}$} \\
\hline Tank 49H Waste & $24.0 \mathrm{~mL} / \mathrm{min}$ & $24.5 \mathrm{~mL} / \mathrm{min}$ \\
Solvent & $6.0 \mathrm{~mL} / \mathrm{min}$ & $6.1 \mathrm{~mL} / \mathrm{min}$ \\
Strip & $1.6 \mathrm{~mL} / \mathrm{min}$ & $1.5 \mathrm{~mL} / \mathrm{min}$ \\
Scrub & $1.6 \mathrm{~mL} / \mathrm{min}$ & $1.6 \mathrm{~mL} / \mathrm{min}$ \\
\hline
\end{tabular}

\subsubsection{Waste Decontamination}

Data for the Tank $49 \mathrm{H}$ waste test show strong performance relative to the target DF values throughout the entire test. The objective was to achieve a DF of 40,000 in an MCU-type 
configuration. Due to a reduced number of stages in the 2-cm contactor apparatus (five stages each for extraction and strip compared to seven stages of each for MCU), the target DF was 1944, assuming 90\% stage efficiency for both extraction and stripping. In order to obtain a DF of 1944, SASSE calculations had to impose a $\mathrm{D}(\mathrm{Cs})$ value for extraction of 36 (instead of the reference value of 60 in Table 4-1) and both scrub and strip values in agreement with the reference values. With the exception of one sample at $24 \mathrm{~h}$ (likely due to sample contamination), all of the measured DF values ranged between $3.80 \mathrm{E}+04$ and $1.08 \mathrm{E}+05$ with an average DF of $\sim 6.78 \mathrm{E}+04$. A plot of the measured DF as a function of time is shown in Figure 4-7. 
Table 4-11. DSS Data for Tank 49H HLW Test

\begin{tabular}{|c|c|c|c|c|c|}
\hline \multicolumn{4}{|c|}{ Feed ${ }^{137} \mathrm{Cs}=1.44 \mathrm{E}+08 \mathrm{dpm} / \mathrm{mL}$} & \multirow[b]{2}{*}{${ }^{137} \mathrm{Cs}$} & \multirow[b]{3}{*}{ DF } \\
\hline & ${ }^{137} \mathrm{Cs}$ & & & & \\
\hline Time (h) & dpm/mL & DF & Time (h) & $\mathbf{d p m} / \mathbf{m L}$ & \\
\hline 0 & $<1.55 \mathrm{E}+02$ & $>9.29 \mathrm{E}+05$ & 13 & $2.51 \mathrm{E}+03$ & $5.74 \mathrm{E}+04$ \\
\hline 0.5 & $3.45 \mathrm{E}+02$ & $4.17 \mathrm{E}+05$ & 14 & $1.88 \mathrm{E}+03$ & $7.66 \mathrm{E}+04$ \\
\hline 1 & $1.52 \mathrm{E}+03$ & $9.47 \mathrm{E}+04$ & 15 & $2.05 E+03$ & $7.02 \mathrm{E}+04$ \\
\hline 1.5 & $1.51 \mathrm{E}+03$ & $9.54 \mathrm{E}+04$ & 16 & $3.79 \mathrm{E}+03$ & $3.80 \mathrm{E}+04$ \\
\hline 2 & $1.50 \mathrm{E}+03$ & $9.60 \mathrm{E}+04$ & 17 & $1.64 \mathrm{E}+03$ & $8.78 \mathrm{E}+04$ \\
\hline 3 & $2.11 \mathrm{E}+03$ & $6.82 \mathrm{E}+04$ & 18 & $2.69 \mathrm{E}+03$ & $5.35 \mathrm{E}+04$ \\
\hline 4 & $1.47 \mathrm{E}+03$ & $9.80 \mathrm{E}+04$ & 19 & $1.43 E+03$ & $1.01 \mathrm{E}+05$ \\
\hline 5 & $1.74 \mathrm{E}+03$ & $8.28 \mathrm{E}+04$ & 20 & $3.11 \mathrm{E}+03$ & $4.63 \mathrm{E}+04$ \\
\hline 6 & $1.90 \mathrm{E}+03$ & $7.58 \mathrm{E}+04$ & 21 & $2.11 \mathrm{E}+03$ & $6.82 \mathrm{E}+04$ \\
\hline 7 & $3.55 E+03$ & $4.06 \mathrm{E}+04$ & 22 & $1.92 \mathrm{E}+03$ & $7.50 \mathrm{E}+04$ \\
\hline 8 & $3.38 \mathrm{E}+03$ & $4.26 \mathrm{E}+04$ & 23 & $2.09 \mathrm{E}+03$ & $6.89 E+04$ \\
\hline 9 & $2.90 \mathrm{E}+03$ & $4.97 \mathrm{E}+04$ & 24 & $3.09 E+04$ & $4.66 \mathrm{E}+03$ \\
\hline 10 & $2.63 E+03$ & $5.48 \mathrm{E}+04$ & 25 & $1.97 \mathrm{E}+03$ & $7.31 \mathrm{E}+04$ \\
\hline 11 & $3.64 \mathrm{E}+03$ & $3.96 \mathrm{E}+04$ & 26 & $1.33 \mathrm{E}+03$ & $1.08 \mathrm{E}+05$ \\
\hline 12 & $2.71 \mathrm{E}+03$ & $5.31 \mathrm{E}+04$ & 27 & $1.84 \mathrm{E}+03$ & $7.83 E+04$ \\
\hline
\end{tabular}

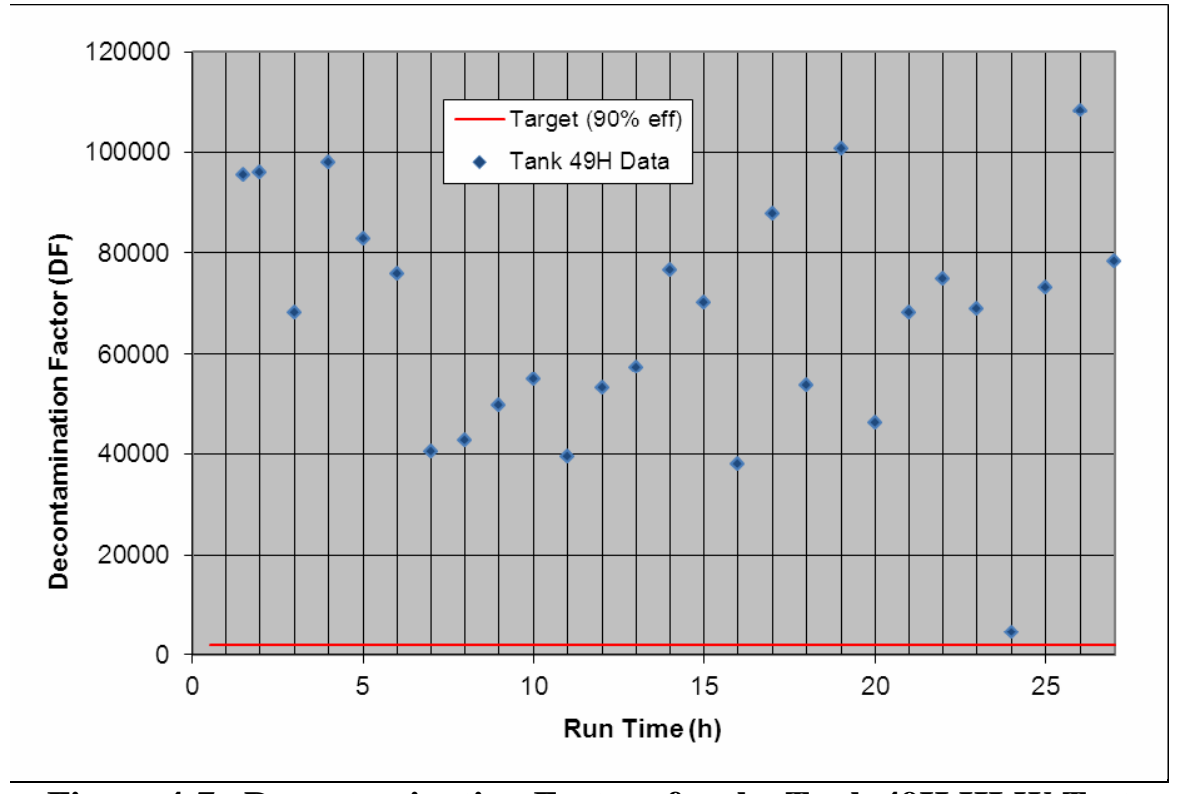

Figure 4-7. Decontamination Factors for the Tank 49H HLW Test

The data were used with $\mathrm{D}(\mathrm{Cs})$ values reported later (see Section4.3.6) to calculate stage efficiencies using the SASSE modeling program. ${ }^{[9]}$ The calculations showed that the stage efficiencies ranged from $94 \%$ to $96 \%$. 


\subsubsection{Concentration Factors}

The strip effluent (SE) and associated CF calculations are listed in Table 4-12 and graphed in Figure 4-8. Concentration factors for the Tank $49 \mathrm{H}$ waste test show a fair amount of variability $( \pm 20 \%$ of the average $\mathrm{CF}$ ), perhaps due to dilution variability during sample preparation and dilution. The uncertainty of the analytical method is only $5 \%$. The data indicate that steady-state operations were achieved after about two hours of operation. Once steady-state operation was achieved the CF was between 11.5 and 18.8 for the remainder of the test with an average CF of 15.9. The average CF is consistent with the average CF of 16.3 calculated from the waste feed and strip feed rates (Table 4-10).

Table 4-12. SE Data for Tank 49H HLW Test

\begin{tabular}{|c|c|c|c|c|c|}
\hline \multicolumn{4}{|c|}{ Feed ${ }^{137} \mathrm{Cs}=1.44 \mathrm{E}+08 \mathrm{dpm} / \mathrm{mL}$} & \multirow[b]{2}{*}{${ }^{137} \mathrm{Cs}$} & \multirow[b]{3}{*}{ CF } \\
\hline & ${ }^{137} \mathrm{Cs}$ & & & & \\
\hline Time (h) & $\mathrm{dpm} / \mathrm{mL}$ & CF & Time (h) & $\mathrm{dpm} / \mathrm{mL}$ & \\
\hline 0 & $9.37 \mathrm{E}+06$ & 0.1 & 13 & $1.86 \mathrm{E}+09$ & 12.9 \\
\hline 0.5 & $5.85 \mathrm{E}+08$ & 4.1 & 14 & $2.01 \mathrm{E}+09$ & 14.0 \\
\hline 1 & $1.20 \mathrm{E}+09$ & 8.3 & 15 & $2.24 \mathrm{E}+09$ & 15.6 \\
\hline 1.5 & $1.39 \mathrm{E}+09$ & 9.7 & 16 & $2.47 \mathrm{E}+09$ & 17.2 \\
\hline 2 & $2.04 \mathrm{E}+09$ & 14.2 & 17 & $2.46 \mathrm{E}+09$ & 17.1 \\
\hline 3 & $2.22 \mathrm{E}+09$ & 15.4 & 18 & $2.30 \mathrm{E}+09$ & 16.0 \\
\hline 4 & $2.45 \mathrm{E}+09$ & 17.0 & 19 & $2.32 \mathrm{E}+09$ & 16.1 \\
\hline 5 & $2.28 \mathrm{E}+09$ & 15.8 & 20 & $2.43 \mathrm{E}+09$ & 16.9 \\
\hline 6 & $2.39 \mathrm{E}+09$ & 16.6 & 21 & $2.43 \mathrm{E}+09$ & 16.9 \\
\hline 7 & $2.67 \mathrm{E}+09$ & 18.5 & 22 & $2.64 \mathrm{E}+09$ & 18.3 \\
\hline 8 & $2.27 \mathrm{E}+09$ & 15.8 & 23 & $2.40 \mathrm{E}+09$ & 16.7 \\
\hline 9 & $2.09 \mathrm{E}+09$ & 14.5 & 24 & $2.36 \mathrm{E}+09$ & 16.4 \\
\hline 10 & $1.84 \mathrm{E}+09$ & 12.8 & 25 & $2.58 \mathrm{E}+09$ & 17.9 \\
\hline 11 & $2.26 \mathrm{E}+09$ & 15.7 & 26 & $1.65 \mathrm{E}+09$ & 11.5 \\
\hline 12 & $2.33 \mathrm{E}+09$ & 16.2 & 27 & $2.71 \mathrm{E}+09$ & 18.8 \\
\hline \multicolumn{6}{|c|}{ Method uncertainty $=5.0 \%$} \\
\hline
\end{tabular}

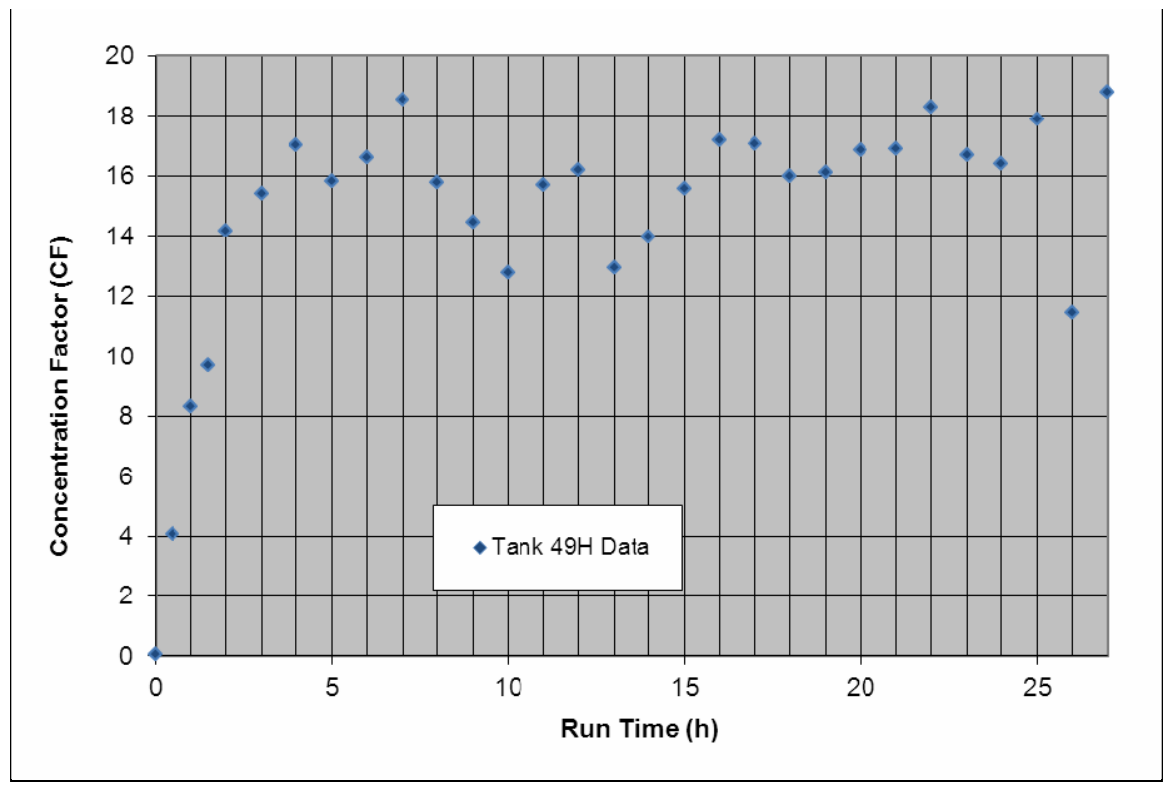

Figure 4-8. Concentration Factors for the Tank 49H HLW Test 


\subsubsection{Concentration of Inorganic Components in the Solvent}

Samples of the stripped solvent as a function of time were collected, digested, and analyzed by ICPMS and ICPES. The data of cations of interest and those above detection limits are shown in Table 4-13. Due to dilution factors, the detection limits for Na and $\mathrm{K}$ were too high to make any meaningful determinations. Other than Cs $\left({ }^{133} \mathrm{Cs}\right.$ and $\left.{ }^{137} \mathrm{Cs}\right)$, no other analytes were consistently present above the concentrations measured in an analytical blank. Of particular interest are Rb, U, and $\mathrm{Pu}$. For $\mathrm{Rb}$ and $\mathrm{Pu}$, the element concentrations are consistently below the detection limits.

The data suggest that a very low concentration of $U$ (Mass 238) has been extracted by the solvent without being stripped. The ${ }^{238} \mathrm{U}$ concentration in the Tank $49 \mathrm{H}$ feed was $\sim 18 \mathrm{mg} / \mathrm{L}$. However, the presence of $\mathrm{U}$ in the 0 -hr sample (before Tank $49 \mathrm{H}$ feed began) and the absence of $\mathrm{U}$ in the 27-hr sample cast doubt on whether $U$ is present. Furthermore, the level of $U$ detected in the samples is near the method detection limit, and with a method uncertainty of $20 \%$, the actual presence of $U$ in the samples is more uncertain. An ongoing SRNL study specifically examined the uptake of actinides onto MaxCalix. In light of the uncertainty of the data in this report, conclusions about actinide uptake on MaxCalix should be deferred until the SRNL data on actinide uptake are reported.

Table 4-13. Inorganic Compositions in the Solvent for Tank 49H HLW Test

\begin{tabular}{|c|c|c|c|c|c|c|c|}
\hline \multicolumn{8}{|c|}{ ICPMS Data (in $\mu \mathrm{g} / \mathrm{g}$ ) } \\
\hline & $\mathbf{0 ~ h r}$ & $6 \mathrm{hr}$ & $12 \mathrm{hr}$ & $18 \mathrm{hr}$ & $24 \mathrm{hr}$ & $27 \mathrm{hr}$ & Blank \\
\hline Mass $85(\mathrm{Rb})$ & 4.00E-02 & $<3.17 \mathrm{E}-02$ & 7.90E-02 & $<3.05 \mathrm{E}-02$ & $<3.35 \mathrm{E}-02$ & $<2.33 \mathrm{E}-02$ & $<3.50 \mathrm{E}-02$ \\
\hline Mass $87(\mathrm{Rb})$ & $<4.00 \mathrm{E}-02$ & $<4.08 \mathrm{E}-02$ & $<4.47 \mathrm{E}-02$ & $<3.92 \mathrm{E}-02$ & $<4.31 \mathrm{E}-02$ & $<3.00 \mathrm{E}-02$ & $<4.50 \mathrm{E}-02$ \\
\hline Mass $133(\mathrm{Cs})$ & 4.64E-01 & $4.10 \mathrm{E}-02$ & 3.60E-01 & 4.89E-01 & 8.20E-02 & 2.98E-01 & $4.60 \mathrm{E}-02$ \\
\hline Mass 137 (Cs) & 4.10E-02 & 2.20E-02 & 2.00E-02 & $<1.74 \mathrm{E}-02$ & $<1.92 \mathrm{E}-02$ & 2.00E-02 & 4.40E-02 \\
\hline Mass $235(\mathrm{U})$ & $<8.90 \mathrm{E}-03$ & $<9.07$ E.03 & $<9.94 \mathrm{E}-03$ & $<8.72 \mathrm{E}-03$ & $<9.58 \mathrm{E}-03$ & $<6.67 \mathrm{E}-03$ & $<1.00 \mathrm{E}-02$ \\
\hline Mass $238(\mathrm{U})$ & 6.30E-02 & 9.20E-02 & 5.40E-02 & 7.40E-02 & 8.80E-02 & $<2.00 \mathrm{E}-02$ & $<3.00 \mathrm{E}-02$ \\
\hline Mass $239(\mathrm{Pu})$ & $<1.33 \mathrm{E}-02$ & $<1.36 \mathrm{E}-02$ & $<1.49 \mathrm{E}-02$ & $<1.31 \mathrm{E}-02$ & $<1.44 \mathrm{E}-02$ & $<1.00 \mathrm{E}-02$ & $<1.50 \mathrm{E}-02$ \\
\hline \multicolumn{8}{|c|}{ ICPES Data (in mg/L) } \\
\hline & $\mathbf{0 ~ h r}$ & $6 \mathrm{hr}$ & $12 \mathrm{hr}$ & $18 \mathrm{hr}$ & $24 \mathrm{hr}$ & $27 \mathrm{hr}$ & Blank \\
\hline $\mathrm{Al}$ & 58.9 & 17.9 & 18.8 & $<12.3$ & 17.6 & 28.7 & 45.9 \\
\hline B & $<5.05$ & $<5.15$ & $<5.65$ & $<4.95$ & $<5.44$ & $<3.79$ & $<5.68$ \\
\hline $\mathrm{Cr}$ & 13.7 & $<11.9$ & $<13$ & $<11.4$ & 16.5 & $<8.75$ & $<13.1$ \\
\hline $\mathrm{Cu}$ & 37.7 & 11 & 32.6 & 13.7 & $56 . .7$ & 28.4 & 51 \\
\hline $\mathrm{Fe}$ & 55.9 & 12.9 & 26.7 & 29.8 & 112 & 17.3 & 15.3 \\
\hline $\mathrm{K}$ & $<91.3$ & $<93.1$ & $<102$ & $<89.5$ & $<98.3$ & $<68.5$ & $<103$ \\
\hline $\mathrm{Mg}$ & 21.2 & 5.93 & $<5.96$ & 5.36 & 6.35 & 9.61 & 11.1 \\
\hline $\mathrm{Na}$ & $<118$ & $<120$ & $<132$ & $<116$ & $<127$ & $<88.5$ & $<133$ \\
\hline $\mathrm{Ni}$ & 23.7 & $<16.5$ & $<18.1$ & $<15.9$ & $<17.4$ & $<12.1$ & $<18.2$ \\
\hline $\mathrm{S}$ & $<267$ & $<272$ & $<298$ & $<262$ & $<287$ & $<200$ & $<300$ \\
\hline $\mathrm{Si}$ & 100 & 34.6 & $<33.5$ & $<29.4$ & $<32.3$ & 77.5 & 55.2 \\
\hline
\end{tabular}

\subsubsection{Second-Phase Carryover}

Second-phase carryover for the Tank $49 \mathrm{H}$ waste test was based on two factors: 1) analyses of effluent streams (Table 4-14), and 2) visible second-phase carry over in the decanters (Table 4-15). The quantities of visible second-phase carry over were negligible. Only a thin film 
( $\sim 0.3 \mathrm{~mL})$ was observed in the SE Decanter. Therefore, the concentrations of solvent in the aqueous effluent streams (Table 4-14) are a measure of second-phase carry over. The average modifier value measured for the DSS by HPLC was $28 \mathrm{mg} / \mathrm{L}$; the average modifier concentration measured using SVOA was $19 \mathrm{mg} / \mathrm{L}$. The concentration of extractant measured by HPLC is consistent with the detected modifier concentration. The ratio of modifier weight to extractant weight in the initial solvent is 3.5. The average ratio of modifier to extractant weights, as measured by HPLC, is 3.3. This result suggests that the modifier measured in the DSS includes second-phase carryover and not only dissolved modifier. With sufficient contact time, modifier is soluble in the DSS to $\sim 17 \mathrm{mg} / \mathrm{L}^{[12]}$ Because modifier represents about $20 \%$ of the total solvent mass, the amount of second-phase carryover in the DSS could have been up to $140 \mathrm{mg} / \mathrm{L}$, although that value may be overstated by as much as 50\% due to modifier solubility in the DSS.

Analyses of second-phase carryover into the SE stream are pending.

Table 4-14. Tank 49H HLW Test Organic Carry Over into the DSS and SE Streams

\begin{tabular}{|c|c|c|c|c|c|c|}
\hline \multirow[b]{2}{*}{ Sample } & \multirow{2}{*}{$\begin{array}{l}\text { VOA (mg/L) } \\
\text { All Analytes }\end{array}$} & \multicolumn{3}{|c|}{ SVOA (mg/L) } & \multicolumn{2}{|c|}{ HPLC (mg/L) } \\
\hline & & Isopar $^{\circledR} \mathrm{L}$ & Modifier & Other Analytes & Modifier & Extractant \\
\hline 8-h DSS & $<0.1$ & na* & 20 & 20 & 29 & 9 \\
\hline 16-h DSS & $<0.1$ & na* & 16 & 22 & 30 & 7 \\
\hline 24-h DSS & $<0.1$ & na* & 22 & 18 & 24 & 10 \\
\hline All SE \#1 & TBD & TBD & TBD & TBD & TBD & TBD \\
\hline All SE \#2 & TBD & TBD & TBD & TBD & TBD & TBD \\
\hline
\end{tabular}

Table 4-15. Tank 49H HLW Test Second-Phase Carryover Rates

\begin{tabular}{|l|l|}
\hline DSS Decanter & $0 \mathrm{~mL}$ of second-phase carry over out of a total flow of $41,100 \mathrm{~mL}$ \\
\hline SE Decanter & $\begin{array}{l}0.3 \mathrm{~mL} \text { of second-phase carry over out of a total flow of } 2,570 \mathrm{~mL} \\
(0.012 \%)\end{array}$ \\
\hline $\begin{array}{l}\text { Solvent Recycle } \\
\text { Decanter }\end{array}$ & $0 \mathrm{~mL}$ of second-phase carry over out of a total flow of 9,630 mL \\
\hline
\end{tabular}

\subsubsection{Stage Data}

The quantity of cesium in the experiment allowed for measurement of distribution ratios in each stage at the end of the test. At the end of the test, a sample of the aqueous stream from each stage was submitted for ${ }^{137} \mathrm{Cs}$ analysis. Next, the remaining aqueous and organic for each stage were equilibrated and sampled. Due to equilibration at ambient temperature $\left(28.6{ }^{\circ} \mathrm{C}\right)$, the $\mathrm{D}(\mathrm{Cs})$ values calculated from the analyses were corrected for temperature $\left(23{ }^{\circ} \mathrm{C}\right.$ for Stages $1-7$ and $33^{\circ} \mathrm{C}$ for Stages 8-12). ${ }^{[10]}$ The activity levels for each stage, the calculated $\mathrm{D}(\mathrm{Cs})$ values, and the temperature-corrected $\mathrm{D}(\mathrm{Cs})$ values are listed in Table 4-16. The activity levels for equilibrium samples and aqueous samples pulled at shut down are plotted in Figure 4-11. 
Table 4-16. Equilibrium Distribution Ratios for Tank 49H HLW Test

\begin{tabular}{|c|c|c|c|c|c|c|c|}
\hline Section & Stage & $\begin{array}{c}\text { Organic } \\
{ }^{137} \text { Cs, } \\
\text { Equilibrium } \\
\text { (dpm/mL) }\end{array}$ & $\begin{array}{l}\text { Aqueous } \\
{ }^{137} \text { Cs, } \\
\text { Equilibrium } \\
\text { (dpm/mL) }\end{array}$ & $\begin{array}{l}\text { Aqueous } \\
{ }_{137} \text { Cs, } \\
\text { Shut Down } \\
\text { (dpm/mL) }\end{array}$ & $\begin{array}{c}\text { Test } \\
\text { Temp } \\
\left({ }^{\circ} \mathrm{C}\right)\end{array}$ & $\mathrm{D}(\mathrm{Cs})$ & $\begin{array}{c}\text { D(Cs), } \\
\text { Temp } \\
\text { Corrected }\end{array}$ \\
\hline Extraction & 1 & $<3.47 \mathrm{E}+03$ & $1.49 \mathrm{E}+05$ & $1.96 \mathrm{E}+03$ & 28.6 & $>42.9$ & $>57.8$ \\
\hline Extraction & 2 & $<4.10 \mathrm{E}+03$ & $2.76 \mathrm{E}+05$ & $6.85 \mathrm{E}+03$ & 28.6 & $>67.3$ & $>90.6$ \\
\hline Extraction & 3 & $6.93 \mathrm{E}+04$ & $4.05 E+06$ & $7.79 \mathrm{E}+04$ & 28.6 & 58.4 & 78.7 \\
\hline Extraction & 4 & $5.75 \mathrm{E}+05$ & $3.91 \mathrm{E}+07$ & $8.39 \mathrm{E}+05$ & 28.6 & 68.0 & 91.5 \\
\hline Extraction & 5 & $7.02 \mathrm{E}+06$ & $3.77 \mathrm{E}+08$ & $1.17 \mathrm{E}+07$ & 28.6 & 53.7 & 72.3 \\
\hline Scrub & 6 & $5.10 \mathrm{E}+06$ & $5.63 \mathrm{E}+08$ & $2.16 \mathrm{E}+08$ & 28.6 & 110 & 161 \\
\hline Scrub & 7 & $6.83 \mathrm{E}+07$ & $5.48 \mathrm{E}+08$ & $2.32 \mathrm{E}+08$ & 28.6 & 8.02 & 10.8 \\
\hline Strip & 8 & $6.84 \mathrm{E}+08$ & $1.18 \mathrm{E}+08$ & $3.89 \mathrm{E}+08$ & 28.6 & 0.17 & 0.14 \\
\hline Strip & 9 & $1.36 \mathrm{E}+08$ & $8.45 \mathrm{E}+06$ & $6.26 \mathrm{E}+07$ & 28.6 & 0.062 & 0.047 \\
\hline Strip & 10 & $7.62 \mathrm{E}+06$ & $4.28 \mathrm{E}+05$ & $9.21 \mathrm{E}+06$ & 28.6 & 0.056 & 0.048 \\
\hline Strip & 11 & $2.19 E+06$ & $1.02 \mathrm{E}+05$ & $1.61 \mathrm{E}+05$ & 28.6 & 0.047 & 0.040 \\
\hline Strip & 12 & $1.06 \mathrm{E}+06$ & $6.57 \mathrm{E}+03$ & $3.40 \mathrm{E}+05$ & 28.6 & 0.006 & 0.005 \\
\hline
\end{tabular}

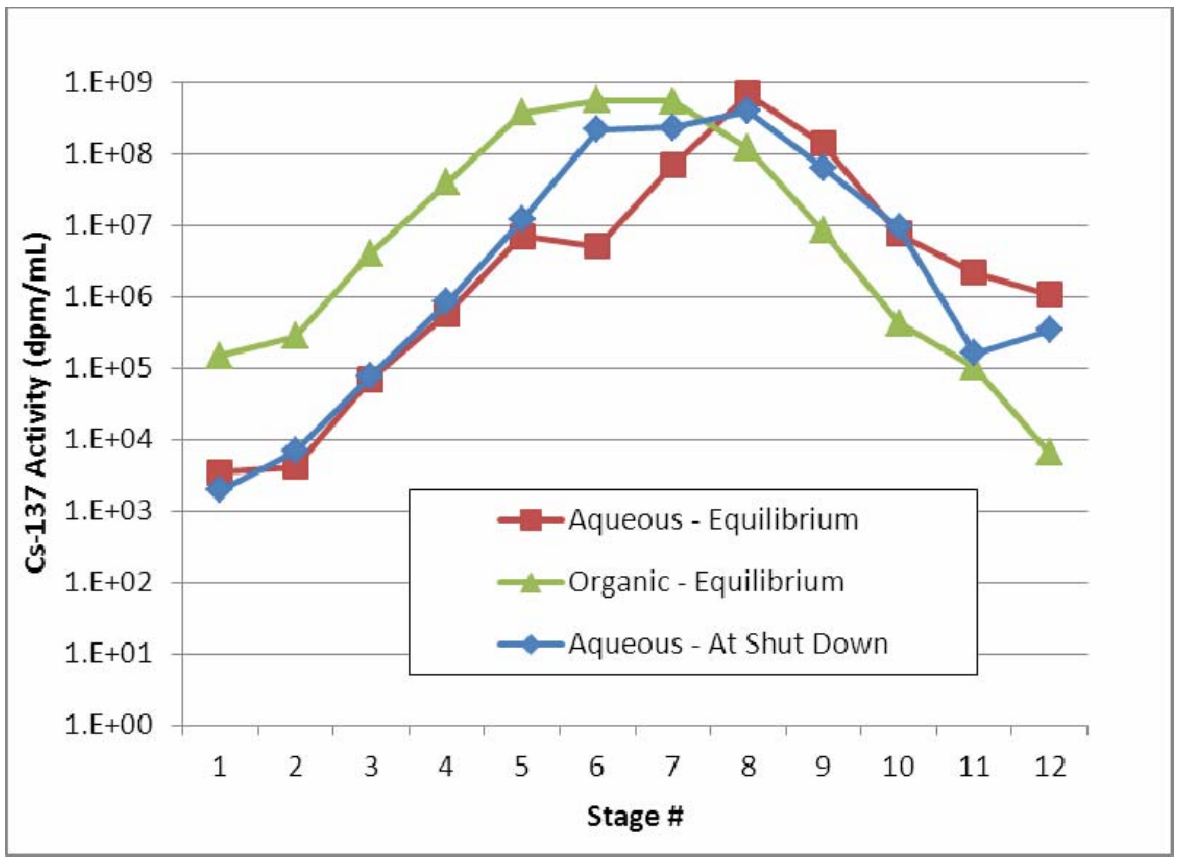

Figure 4-9. Stage Sample Data for the Tank 49H HLW Test

The similarity of both the equilibrium and shut-down aqueous data, particularly for Stages 1-5, 710, and 12 lend confidence to the data-collection techniques. It also indicates that the stages have achieved equilibrium in the contactors. The data also suggest that problems were encountered during the collection of Stage 6 equilibrium and the Stage 11 shut-down aqueous samples. 
The shapes of the aqueous and organic curves in Figure 4-9 have the expected shape relative to each other and provide a contrast to the data presented for the non-radioactive simulant test (Figure 4-4). The $\mathrm{D}(\mathrm{Cs})$ values for the extraction section (Stages 1-5) are in the acceptable range and in general agreement with the ESS test data (Table 4-1).

In contrast, the $\mathrm{D}(\mathrm{Cs})$ values for the scrub and strip sections are not in the expected ranges. ESS values for scrub are 3.5-5.0 for the first scrub stage (Stage 6) and 1.0-3.0 for the second scrub stage (Stage 7). ${ }^{[8]}$ The calculated $\mathrm{D}(\mathrm{Cs})$ scrub values for the Tank $49 \mathrm{H}$ test were 161 for Stage 6 and 10.8 for Stage 7 . The apparent failure of the scrub section also produced less-than-optimal stripping as inefficient scrubbing would impact the $\mathrm{pH}$ of the strip section. Data from the ESS tests determined values for strip of 0.004-0.010 for the first strip stage (Stage 8) and $~ 0.002-0.009$ for subsequent strip stages (Stage 9-12). In the Tank 49H test, the D(Cs) value in Stage 8 started high (0.14) and gradually decreased from stage to stage until reaching a low value of 0.005 in Stage 12. Only the value for Stage 12 was in the expected range. However, these $\mathrm{D}(\mathrm{Cs})$ results show the robustness of the process as the overall process exceeded the target DF values even with the scrub and strip sections not performing as predicted in the ESS tests.

The SASSE modeling program was used to assess the impact of using the reference scrub and strip values (Table 4-1) instead of the measured values of Table 4-16. An average extraction $\mathrm{D}(\mathrm{Cs})$ value of 78.2 was used to reflect the average extraction $\mathrm{D}(\mathrm{Cs})$ data from the Tank $49 \mathrm{H}$ waste test. A plot of both data sets is shown in Figure 4-10. The calculated DF for the test with reference scrub and strip yielded a DF of 99,300, compared to a DF of 67,400 for the Tank $49 \mathrm{H}$ waste test. With reference scrub and strip, the ${ }^{137} \mathrm{Cs}$ activity in the DSS is reduced from $3.47 \mathrm{E}+03 \mathrm{dpm} / \mathrm{mL}$ (for the Tank $49 \mathrm{H}$ waste test) to $1.43 \mathrm{E}+03 \mathrm{dpm} / \mathrm{mL}$. It should be noted, however, that this incremental improvement in decontamination reflects only a small fraction of the initial ${ }^{137} \mathrm{Cs}$ in the Tank $49 \mathrm{H}$ waste feed $(1.44 \mathrm{E}+08 \mathrm{dpm} / \mathrm{mL})$.

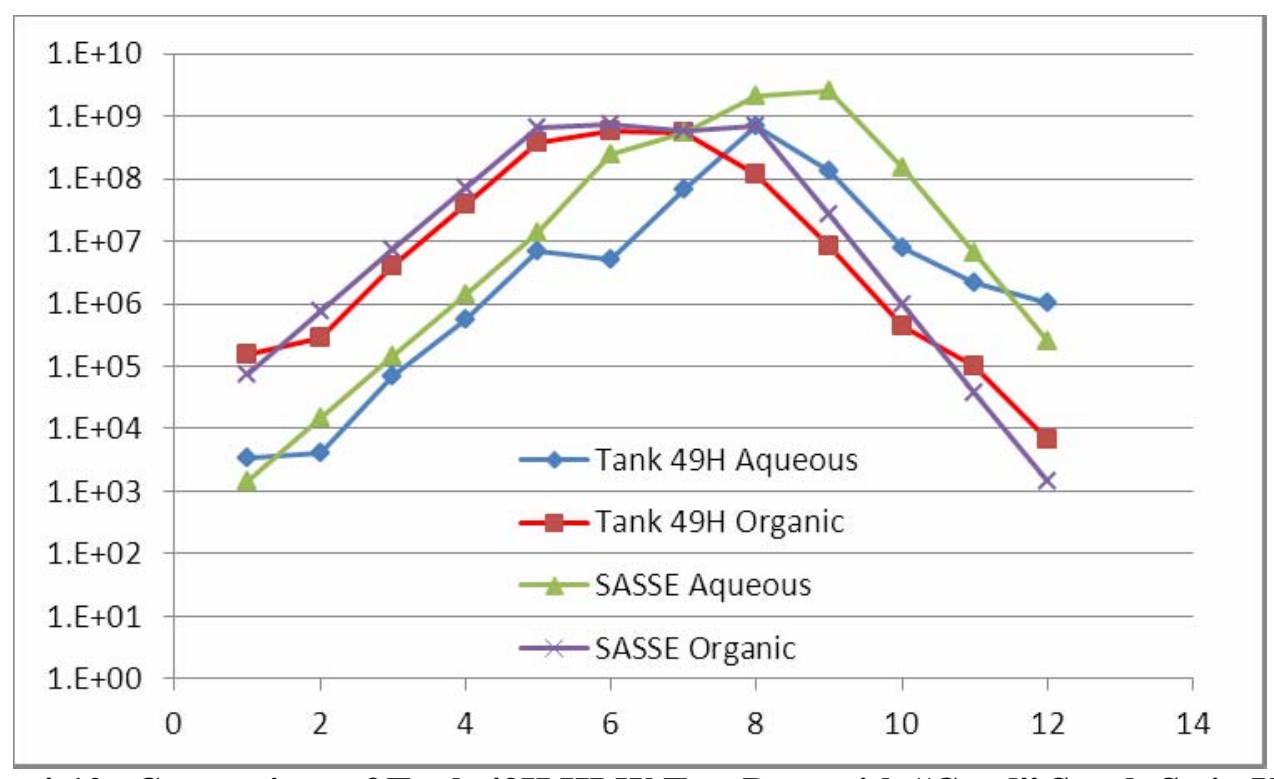

Figure 4-10. Comparison of Tank 49H HLW Test Data with “Good” Scrub-Strip Values

The equilibrium data were used to calculate stage efficiencies for the Tank $49 \mathrm{H}$ waste test using the SASSE modeling program. These calculations determined that average extraction and strip stage efficiencies were $\sim 95.5 \%$. For the minimum DF value of $3.80 \mathrm{E}+04$, the calculated stage 
efficiencies were $\sim 94 \%$. This result further affirms that the solutions in the stages were at or near equilibrium.

When the data shown in Table 4-16 were tabulated, $\mathrm{pH}$ test strips were used to measure the $\mathrm{pH}$ of the aqueous phase in each stage. The resulting $\mathrm{pH}$ values (Table 4-17) suggest that there may be excess $\mathrm{NaOH}$ carryover into the scrub stages as indicated by the high $\mathrm{pH}$ reading in Stage 7 . The carryover may help explain the mediocre stripping values seen in Table 4-16.

Table 4-17. Stage pH Measurements for the Tank 49H HLW Test

\begin{tabular}{|c|c|c|c|c|c|}
\hline Contactor\# & Type & $\mathbf{p H}$ & Contactor\# & Type & $\mathbf{p H}$ \\
\hline 1 & extraction & 14 & 7 & Scrub & 14 \\
\hline 2 & extraction & 14 & 8 & strip & 7 \\
\hline 3 & extraction & 14 & 9 & strip & 7 \\
\hline 4 & extraction & 14 & 10 & strip & 7 \\
\hline 5 & extraction & 14 & 11 & strip & 7 \\
\hline 6 & Scrub & 14 & 12 & strip & 7 \\
\hline
\end{tabular}

With the scrub feed $(0.025 \mathrm{M} \mathrm{NaOH})$ entering Stage 7 , the expectation is for the $\mathrm{pH}$ in Stage 7 to be less than 14. It is not until Stage 8 that the readings are in the expected range. However, the readings probably contain a high level of uncertainty. Measuring the $\mathrm{pH}$ values though the cell window using colorimetric strips can be problematic, especially near $\mathrm{pH}$ 7. While there is a clear delineation between a result of 14 and 7 , a $\mathrm{pH}$ result of 7 has a likely uncertainty of $\pm 1 \mathrm{pH}$ unit.

\subsubsection{Stage Temperatures}

On the test apparatus, thermocouple probes were inserted into holes in each stage of the stainless steel contactor blocks. However, the holes were closer to the top of the contactor blocks and the contactor motor than the bottom. In some cases, it was found that heat from the motor caused the block temperature to not reflect the temperature of the liquid in the contactor. Consequently, thermocouples were also installed in liquid outlet lines of Stages 1, 3, 10, and 12 for comparison with the block temperatures. Figure 4-11 compares the liquid and block temperatures for Stages $1,3,10$, and 12. The data show that the block and liquid temperatures of the extraction stages (Stages 1 and 3) show good agreement while the strip stages (Stages 10 and 12) depict the impact of the motor heat in the warm shielded cell environment. For this reason, the liquid temperature measurements are considered the more reliable measurements. 


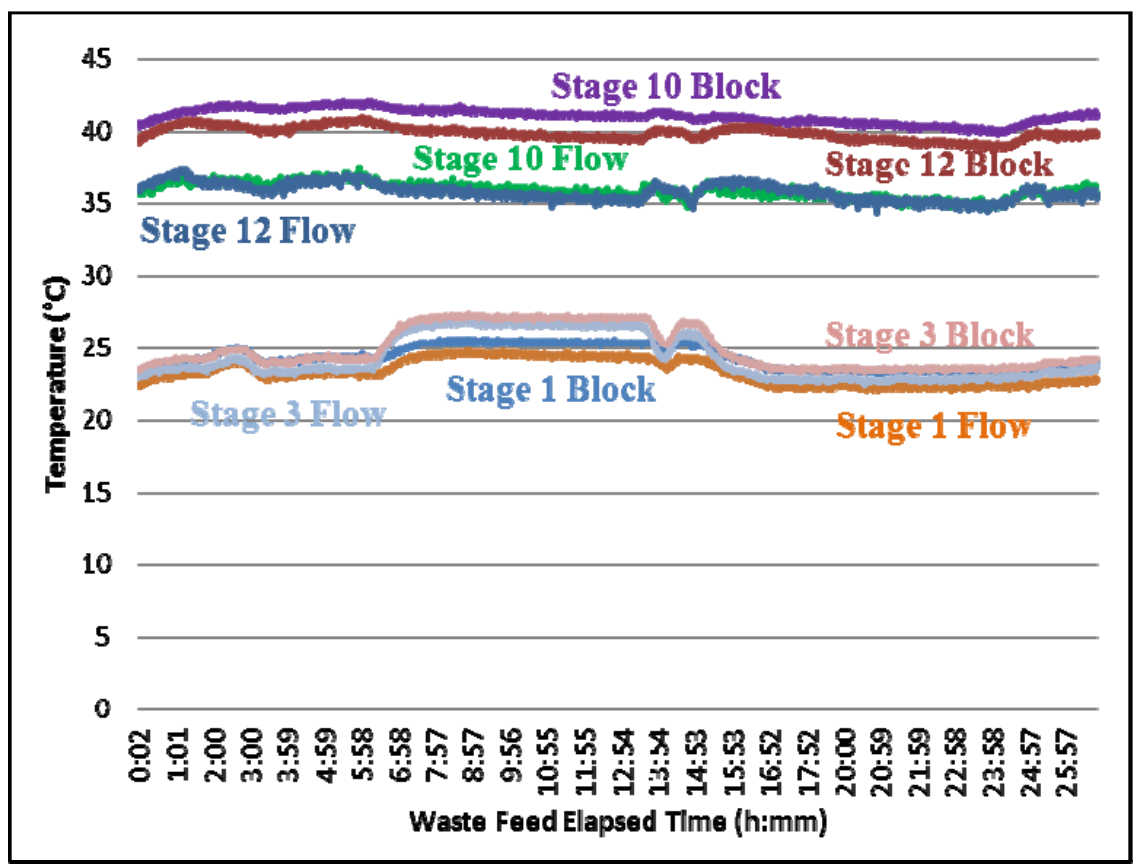

Figure 4-11. Comparison of Contactor Block and Flow Temperatures

Figure 4-11 allows for a more accurate interpretation of Figure 4-12. Figure 4-12 shows the timetemperature profiles for three extraction, two scrub, and three strip stages. Some fluctuation of temperatures occurred throughout the test as a result of temperature changes in the shielded cells and inadvertent feed-line chiller shut downs between $6.0 \mathrm{~h}$ and $14.5 \mathrm{~h}$ after waste feeding began. Based on the data of Figure 4-11 and Figure 4-12, it can be concluded that the temperature changes had a significant impact on the temperatures of Stages 3-6, but that the impact on the other stages was less-pronounced. Regardless of the magnitude of the temperature changes, the waste decontamination data (Figure 4-7) exhibit no measurable change in overall DF as a function of temperature. 


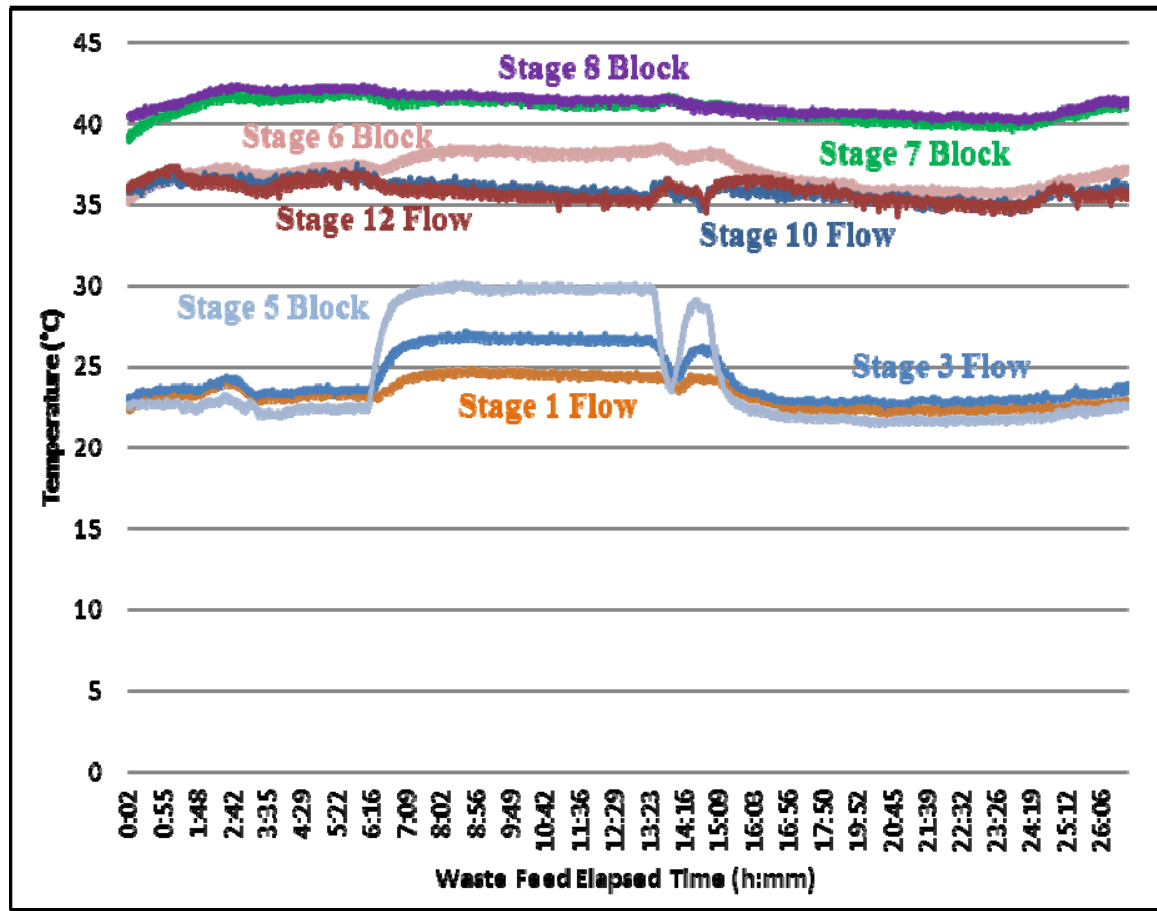

Figure 4-12. Comparison of Contactor Stage Temperatures for Tank 49H HLW Test

The overall impact of temperature may be muted by suspected inefficient operation of the scrub section. It appears that inefficient operation of the scrub stages led to less-than-optimal operation of the strip section. Consequently, the solvent leaving Stage 12 and being fed back into Stage 1 was not as free of cesium as it could have been. This led to a plateau of cesium removal after Stage 3 in the extraction section. It is postulated that if the strip section had operated correctly, lower cesium concentrations in the DSS would have been observed and impact of temperature would have been measurable. Regardless, the overall system out-performed the test objectives.

\subsubsection{Solvent Degradation and Impurities}

Gamma scan analysis of a solvent reservoir sample after the test showed that the solvent reservoir contained $1.07 \mathrm{E}+05 \mathrm{dpm} / \mathrm{mL}$ of ${ }^{137} \mathrm{Cs}$. Analyses of the solvent return samples (exiting Stage 12) contained an average ${ }^{137} \mathrm{Cs}$ concentration of $1.06 \mathrm{E}+05 \mathrm{dpm} / \mathrm{mL}$. Analyses of the solvent reservoir sample before (ORG_0) and after 25 solvent turnovers (ORG_27) using SVOA and HPLC are provided in Table 4-18.

Table 4-18. Analyses of Solvent - Before and After Tank 49H HLW Test (mg/L)

\begin{tabular}{|c|c|c|c|c|c|c|}
\hline \multirow[b]{2}{*}{ Sample } & \multicolumn{3}{|c|}{ SVOA } & \multicolumn{2}{|c|}{ HPLC } & \multirow{2}{*}{$\begin{array}{l}\text { Density } \\
\text { (g/mL) }\end{array}$} \\
\hline & Isopar $^{\circledR} \mathbf{L}$ & Modifier & Other & Modifier & Extractant & \\
\hline Org_0 & TBD & TBD & TBD & 173000 & 46600 & 0.852 \\
\hline Org_27 & TBD & TBD & TBD & 186000 & 48400 & 0.857 \\
\hline
\end{tabular}

Within analytical uncertainty, there was no change in the composition of the solvent. However, the data suggests that Isopar ${ }^{\circledR} \mathrm{L}$ evaporated during the test. An increase in concentration was observed by HPLC for both modifier (7.5\%) and extractant (3.9\%). The evaporation of Isopar ${ }^{\circledR} \mathrm{L}$ 
is consistent with MCU operating experience with BOBCalixC6 solvent and was also observed for the simulant waste test (Table 4-9). Analyses of Isopar ${ }^{\circledR} \mathrm{L}$ and modifier by SVOA are pending.

\subsection{Assessment of Process Performance}

\subsection{Hydraulic Performance}

Large-scale centrifugal contactors have been operated at SRS for many years without hydraulic performance problems. Hydraulic performance of centrifugal contactors tends to improve with increasing overall dimensions. Large contactors are easier to operate because 1) they promote better phase separation, 2) there are higher head pressures and liquid momentum for transferring liquids between stages, 3) process liquid flow rates are high enough for accurate pumping and measurement, and 4) surface-to-volume effects are reduced.

Hydraulic performance in 2-cm centrifugal contactors provides an overall indication of flowsheet behavior. Experience indicates that when the system hydraulic operation is acceptable, overall flowsheet performance will match expectations. Hydraulic performance is particularly important in 2-cm centrifugal contactors because of small head pressures and high surface-to-volume ratios. Even minor process anomalies or configuration changes can completely disrupt process operations.

Experiments at ANL using CSSX simulated waste in similar 2-cm centrifugal contactors reported that the maximum attainable flow rates were $60 \mathrm{~mL} / \mathrm{min}$. For the $2-\mathrm{cm}$ contactor tests discussed in this report, combined flow in the extraction section was $31.6 \mathrm{~mL} / \mathrm{min}$. This difference between the actual and maximum flow rates may explain why the contactors in this set of experiments operated without any hydraulic incidents while the initial SRNL 2-cm testing of the CSSX flowsheet experienced many upsets operating at a combined flow of 55-58 $\mathrm{mL} / \mathrm{min}^{[7]}$

Furthermore, the lower flow rates for the current tests could facilitate higher stage efficiencies than those of the original CSSX tests. The lower flow rates enable longer contact and separation times in the contactors. Furthermore, it has been shown that NGCS has faster extraction kinetics than the baseline solvent. ${ }^{[13]}$ Calculations determined the stage efficiency for the current tests with MaxCalix to be $89-91 \%$ for the non-radioactive simulant test and 94-96\% for the Tank $49 \mathrm{H}$ radioactive waste test. The first SRNL CSSX tests using BOBCalixC6 solvent yielded an efficiency of $82-84 \%$ for the Tank 37/44F radioactive waste test. ${ }^{[7]}$

Related to the hydraulic performance is the issue of second-phase carryover. Second-phase carryover is defined as an unwanted phase observed exiting in a primary product stream. Excessive second-phase carryover of organic in aqueous streams is indicative of poor hydraulic performance and can lead to large losses of solvent.

The exceptional hydraulic performance of the contactors for the current tests was validated with low quantities of second-phase carryover. There was no detectable second-phase carryover in the DSS decanter or in the solvent recycle decanter for either the non-radioactive or radioactive waste tests. The SE decanter contained $0.056 \%$ solvent carryover for the non-radioactive simulant test and $0.012 \%$ for the Tank $49 \mathrm{H}$ waste test. The amount of solvent measured in the DSS and SE streams for the non-radioactive test was $<50 \mathrm{mg} / \mathrm{L}$. One DSS sample showed $98 \mathrm{mg} / \mathrm{L}$ modifier without Isopar ${ }^{\circledR} \mathrm{L}$; the result may be indicative of an errant analysis. The amount of solvent measured in the DSS stream for the Tank $49 \mathrm{H}$ waste test could have been as much as $\sim 140 \mathrm{mg} / \mathrm{L}$, although that value may be overstated by about $50 \%$ due to modifier solubility in the DSS. The data for the concentration of solvent in the SE are pending. 


\subsection{Waste Decontamination}

One leading measure of system performance is the waste DF in the extraction section. The waste enters Stage 5 where it is combined with scrub solution, and it exits Stage 1. Extraction is primarily affected by hydraulic performance, stage temperatures, and cesium concentration in the solvent feed stream. The DF required for the demonstration is 1944 for stage efficiencies of $90 \%$. The calculation imposed a $\mathrm{D}(\mathrm{Cs})$ value for extraction of 36 (compared to the target value of 50) to generate a DF value of 40,000 , assuming reference scrub and strip stage operation. For seven stages of centrifugal contactors in MCU operating at a nominal efficiency of $90 \%$, this calculation would yield a DF of 40,000 .

For the non-radioactive simulant testing the DF ranged from $3.9 \mathrm{E}+03$ to $>6.6 \mathrm{E}+03$ with an average of $>5.9 \mathrm{E}+03$ for the entire test. Testing with Tank $49 \mathrm{H}$ waste yielded a DF between $3.80 \mathrm{E}+04$ and $1.08 \mathrm{E}+05$ with an average of $\sim 6.78 \mathrm{E}+04$ for the entire test. A single low value $(\mathrm{DF}=4.66 \mathrm{E}+03)$ at $24 \mathrm{~h}$ of the Tank $49 \mathrm{H}$ test is likely the result of sample contamination. Nonetheless, the average DF for the entire test includes that low value. The data for both tests are listed in Table 5-1. Both tests surpassed the waste DF target.

The order-of-magnitude difference in average DF for the non-radioactive simulant test and Tank $49 \mathrm{H}$ test raises a question about its cause. The $\mathrm{D}(\mathrm{Cs})$ values from ESS data for the two waste solutions (Table 4-1) indicate that the average DF values should be about the same. The average $\mathrm{D}(\mathrm{Cs})$ extraction value for the Tank $49 \mathrm{H}$ waste test is $78.2 \pm 3.9$ while the average value for the waste simulant is $71 \pm 14$ (average of Stage 1-3 and 5); however, due to the uncertainty of the analytical methods, the difference is not statistically significant. Also, SASSE calculations show that when $\mathrm{D}(\mathrm{Cs})$ values are high for extraction and low for stripping, then minor changes in stage efficiency can have a large effect on DF.

Table 5-1. Measured DF Values for Simulant and Tank $49 H$ Tests

\begin{tabular}{|l|c|c|c|c|}
\hline Test & Target & Minimum & Maximum & Average \\
\hline Non-Radioactive Simulant & 1944 & $3.9 \mathrm{E}+03$ & $>6.6 \mathrm{E}+03$ & $>5.9 \mathrm{E}+03$ \\
\hline Tank 49H & 1944 & $3.80 \mathrm{E}+04$ & $1.08 \mathrm{E}+05$ & $6.78 \mathrm{E}+04$ \\
\hline
\end{tabular}

\subsection{Concentration factor}

To reduce the volume of liquid waste sent to the DWPF, a target CF of 15 was established. When the process chemistry is properly controlled and both waste and solvent DFs are adequate, the concentration factor is controlled by the ratio of the waste feed to the strip feed. The CF can also be calculated as the ratio of the Cs concentration in the SE stream and the Cs concentration in the waste feed.

For the non-radioactive test, the CF based on the pump feed rates was 14.7. The ratio of the Cs concentrations for the SE and waste feed streams was 12.6. However, the uncertainty associated with the non-radioactive Cs measurements (using ICPMS) was 20\%. For the Tank $49 \mathrm{H}$ test, the CF based on the pump feed rates was 16.3. The ratio of the Cs concentrations for the SE and waste feed streams was 15.9 with a Cs-measurement uncertainty of 5.0\%. Therefore, within uncertainty, both tests met the CF target.

\subsection{Solvent Turnover}

A total solvent turnover requirement of 20 was established for each test. A secondary intent of this requirement is to subject the solvent to sufficient contact with Tank $49 \mathrm{H}$ waste to determine what negative effects, if any, would result from both solvent recycle and from short-term 
exposure to the radiation field in a processing environment. Experiments at ORNL, SRNL, and INEL - as well as operating experience - have shown that the BOBCalixC6 solvent has excellent radiation and chemical stability such that there should be no long-term effects associated with exposing the solvent to the Tank $49 \mathrm{H}$ waste. Since only the suppressor and extractant are chemically different in the NGCS, one would not expect to observe problematic behavior in this test.

More significantly, the current testing does not incorporate a washing cycle for the solvent. Also, for NGCS, the potential exists for refluxing borates in the system with potential risk of polyborate formation and subsequent precipitations. Early testing by ORNL had examined behavior in as many as 10 cycles of simulant contacts. Hence, 20 turnovers were chosen in this test as a means of examination of the risk while limiting to a practical amount of actual waste sample. The 20 turnovers is a significant duration relative to potential impact of loss of suppressor. ORNL has reported appreciable losses in the range of $2.6 \%$ per cycle which would equate to approaching $50 \%$ projected for these tests. ${ }^{[14]}$ Future analyses will examine the actual losses.

For the non-radioactive simulant test, the solvent was subjected to $\sim 20$ solvent turnovers, allowing for solvent loss due to sampling. Analyses of the solvent before and after the test showed no solvent degradation or changes in the relative compositions of components in the solvent, within analytical uncertainty. It appears as though Isopar ${ }^{\circledR} \mathrm{L}$ is evaporating from the solvent; however, the losses are within analytical uncertainty. ICPES analyses show the accumulation of minor metal concentrations $[\mathrm{Ca}=58.7 \mathrm{mg} / \mathrm{L}, \mathrm{Cu}=37.2 \mathrm{mg} / \mathrm{L}, \mathrm{Fe}=14.7 \mathrm{mg} / \mathrm{L}$, $\mathrm{Na}=18.5 \mathrm{mg} / \mathrm{L}, \mathrm{Ni}=22.6 \mathrm{mg} / \mathrm{L}, \mathrm{S}=42.1 \mathrm{mg} / \mathrm{L}$, and $\mathrm{Si}=67.8 \mathrm{mg} / \mathrm{L}]$, but these metal concentrations did not seem to impact solvent performance. The sulfur accumulation in the solvent may not have reached a steady concentration within the test period. No measurable boron accumulation (indication of borate) was detected in the solvent after $\sim 20$ solvent turnovers.

For the Tank $49 \mathrm{H}$ waste test, the solvent was subjected to $\sim 25$ solvent turnovers, allowing for solvent loss due to sampling. Sampling losses were higher in the radioactive-waste test due to the constraints of operating in the Shielded Cells facility. Similar to the non-radioactive simulant test, analyses of the solvent before and after the test showed no solvent degradation or changes in the relative compositions of components in the solvent, within analytical uncertainty. Also, it appears as though Isopar ${ }^{\circledR} \mathrm{L}$ is evaporating from the solvent, although the evaporative losses are within analytical uncertainty. Analyses of the solvent before and after the test by SVOA and FTIR are pending.

\subsection{Conclusions}

The CSSX process flowsheet for the decontamination of HLW with a MaxCalix-based solvent system was demonstrated in a 12-stage, 2-cm contactor apparatus. Simulated and actual Tank $49 \mathrm{H}$ wastes were processed in two tests, each lasting at least $24 \mathrm{~h}$. Results of the two tests support the following conclusions.

Waste Decontamination: The test with the Tank $49 \mathrm{H}$ waste sample yielded an average DF for five extraction, two scrub, and five strip stages of $6.78 \mathrm{E}+04$ at a nominal stage efficiency of $95 \%$. Applying those results to MCU, which has seven extraction, two scrub, and seven strip stages operating at a nominal efficiency of $90 \%$, this translates into a DF of $\sim 388,000$; at a nominal stage efficiency of 95\%, the DF in MCU would be in excess of 3.2 million. The Tank $49 \mathrm{H}$ test also confirms that minor components in the Tank $49 \mathrm{H}$ waste do not impact the process DFs compared to simulated wastes. 
Hydraulic Performance: The 2-cm contactor apparatus operated without any hydraulic issues in both the non-radioactive simulant and the Tank 49H HLW tests. No flow disruptions were encountered and pumping rates remained stable throughout both the 24-hour non-radioactive test and the 27-hour Tank $49 \mathrm{H}$ test. The ability to operate without issue may be the result of operating at $\sim 53 \%$ of its expected throughput capacity. Hydraulic stage efficiencies in the extraction and strip sections were calculated at $89-91 \%$ for the non-radioactive simulant test and 94-96\% for the Tank 49H HLW test. Considering the difficulties inherent with operating a bank of 2-cm contactors, hydraulic performance in these two tests was exceptional.

Solvent Retention: Carryover of organic solvent in aqueous streams (and aqueous in organic streams) is much less than $0.1 \%$ when processing either Tank $49 \mathrm{H}$ radioactive waste or its simulant. No second-phase carryover was noted in either the DSS or solvent recycle streams. Second-phase carryover for the SE stream in the non-radioactive and radioactive tests were $0.056 \%$ and $0.012 \%$, respectively. Minor components in the high level radioactive waste did not affect the ability of the contactors to efficiently separate the solvent and aqueous phases. Carryover of solvent into the DSS was as high as $140 \mathrm{mg} / \mathrm{L}$, although that value may be overstated by about $50 \%$ due to modifier solubility in the DSS. Analyses of the SE solution are pending.

Cesium Concentration: A steady-state CF of 15.9 was achieved with Tank 49H HLW, as determined from activity data. Calculations based on the pump flow rates indicate a CF of 16.3 for the Tank $49 \mathrm{H}$ test.

\subsection{Future Work}

Three areas of future work are recommended. The first is to resolve apparent issues with scrubbing and stripping. Although both process demonstrations exceeded the programmatic targets, the process effectiveness was limited by the stripping of Cs from the solvent into $\mathrm{H}_{3} \mathrm{BO}_{3}$. Expectations based on batch tests indicated that the process should have been extraction-limited. Studies would identify the source of the Cs-stripping inefficiency and demonstrate correct resolution. In particular, efforts would determine if the issue is related to the scrub process (either hydraulics or chemistry), stripping (chemistry), or whether the omission of a solvent-wash stage contributed to the less-than-optimal stripping observed.

It is recommended that a Tank 49H HLW demonstration be conducted with blended solvent using the 2-cm contactor apparatus. The current plan for introducing the MaxCalix solvent system into MCU involves blending it in with the current BOBCalixC6 solvent system to avoid disposal cost for the prior solvent and to avoid extensive solvent removal efforts. A similar approach would benefit the Salt Waste Processing Facility. Batch testing indicates that the blend strategy will work. However, SRNL recommends that a 24-hour flow through test be completed with Tank $49 \mathrm{H}$ salt simulant spiked with ${ }^{137} \mathrm{Cs}$ to address potential risks associated with the blending strategy.

SRNL recommends that a test with MaxCalix be performed on a waste solution with high potassium content. Potassium has the potential to interfere with Cs extraction. The test would use a ${ }^{137} \mathrm{Cs}$ spiked simulant waste solution. It is recommended that the simulant solution resemble a Hanford waste solution with the objective of transferring this technology for the removal of Cs at Hanford using MaxCalix in the CSSX process. 


\subsection{References}

1. P. V. Bonnesen, L. H. Delmau, T. J. Haverlock, and B. A. Moyer, Alkaline-Side Extraction of Cesium from Savannah River Tank Waste Using a Calixarene-Crown Ether Extractant, ORNL/TM-13704 (1998).

2. L. H. Delmau, G. J. Van Berkel, P. V. Bonnesen, and B. A. Moyer, Improved Performance of the Alkaline-Side CSEX Process for Cesium Extraction from Alkaline High-Level Waste Obtained by Characterization of the Effect of Surfactant Impurities, ORNL/TM-1999/209 (1999).

3. B. A. Moyer, P. V. Bonnesen, L. H. Delmau, F. V. Sloop, Jr., N. J. Williams, J. F. Birdwell, Jr., D. L. Lee, R. A. Leonard, S. D. Fink, T. B. Peters, and M. W. Geeting, Development of the Next-Generation Caustic-Side Solvent Extraction (NG-CSSX) Process for Cesium Removal from High-Level Tank Waste, Paper 11346, Proc. Waste Management 2011, February 27-March 3, 2011, Phoenix, AZ; Waste Management Symposia, Tempe, AZ, (2011).

4. S. D. Fink and B. A. Moyer, EM-30 Technology Development and Deployment (TDD) Program Task Plan, Task Plan for WP-2 Task 2.1.6 Next Generation Solvent, SRNL-RP2011-00959, Rev. 0 (July 2011).

5. L. H. Delmau, J. F. Birdwell, J. McFarlane, and B. A. Moyer, Robustness of the CSSX Process to Feed Variation: Efficient Cesium Removal from the High Potassium Wastes at Hanford, Solvent Extraction and Ion Exchange, 28:1, 19-48 (2010).

6. T. B. Peters and S. D. Fink, Results from the First Extraction-Scrub-Strip Testing Using Improved Solvent Formulations and Actual Savannah River Site Waste, SRNL-STI-201000586 (September 2010).

7. S. G. Campbell, M. W. Geeting, C. W. Kennell, J. D. Law, R. A. Leonard, M. A. Norato, R. A. Pierce, T. A. Todd, D. D. Walker, W. R. Wilmarth, Demonstration of Caustic-Side Solvent Extraction with Savannah River Site High Level Waste,WSRC-TR-2001-00223 (April 2001).

8. B. A. Moyer, Optimized NG-CSSX Solvent Composition, ORNL-LTR-NGCSSX-002 (2010).

9. R. A. Leonard and M. C. Regalbuto, "Spreadsheet Algorithm for Stagewise Solvent Extraction,” Solvent Extraction and Ion Exchange, 125, 909-930 (1994).

10. N. J. Williams and B. A. Moyer, Temperature Dependence of the Next Generation Caustic Side Solvent Extraction (NG-CSSX) Process Solvent), ORNL-LTR-NGCSSX-012 (2011).

11. B. D. Roach, N. J. Williams, N. C. Duncan, and B. A. Moyer, Effect of Possible Impurities on the Performance of the Next Generation Caustic Side Solvent Extraction (NG-CSSX) Process, ORNL-LTR-NGCSSX-013 (2011).

12. B. A. Moyer, S. D. Alexandratos, P. V. Bonnesan, G. M. Brown, J. E. Caton, L. H. Delmau, C. R. Duchemin, T. J. Haverlock, T. G. Levitskaia, M. P. Maskarinec, F. V. Sloop, and C. L. Stine, Caustic-Side Solvent Extraction Chemical and Physical Properties Progress in FY2000 and FY2001, ORNL/TM-2001/285 (2001).

13. N. J. Williams and B. A. Moyer, Kinetics of Cesium Extraction and Stripping in the Next Generation Caustic Side Solvent Extraction (NG-CSSX) Process, ORNL-LTR-NGCSSX-014 (2011).

14. B. D. Roach, N. J. Williams, N. C. Duncan, and B. A. Moyer, $N, N$ '-Dicyclohexyl- $N^{\prime \prime}-$ isotridecylguanidine Suppressor Variants for the Next Generation Caustic Side Solvent Extraction (NG-CSSX) Process, ORNL-LTR-NGCSSX-018 (2011) 


\subsection{Appendices}

\subsection{Appendix A. Preparation of 45 Liters of Tank 49H Simulant Salt Solution}

\begin{tabular}{|c|c|c|c|}
\hline Step & & $\begin{array}{l}\text { Quantity } \\
\text { Added }\end{array}$ & Unit \\
\hline 1 & To a 50 L carboy, add DI water. & 5 & $\mathrm{~L}$ \\
\hline 2 & Agitate the water at a moderate speed. Maintain mixing until simulant is filtered. & & \\
\hline \multirow[t]{2}{*}{3} & Add sodium hydroxide slowly after any adjustment if in solution with water & 12.286 & $\mathrm{~kg}$ \\
\hline & $\begin{array}{l}\text { (NOTE: Addition of } \mathrm{NaOH} \text { to water will generate heat. A slow addition will } \\
\text { minimize any water loss due to evaporation. A covered vessel will also help to } \\
\text { limit water loss if the vapor is condensed and returned to vessel.) }\end{array}$ & & \\
\hline 4 & Agitate the solution until all solids are fully dissolved. & & \\
\hline 5 & Allow the solution to cool to room temperature before proceeding. & & \\
\hline 6 & Add the aluminum nitrate nonahydrate adjusted if in solution with water & 5.33 & $\mathrm{~kg}$ \\
\hline 7 & Agitate the solution until all solids are fully dissolved. & & \\
\hline \multirow[t]{2}{*}{8} & Allow the solution to cool to at below $55^{\circ} \mathrm{C}$. & & \\
\hline & $\begin{array}{l}\text { Add the remaining chemicals below, keeping the temperature at approximately } \\
50-70^{\circ} \mathrm{C} \text { for the remainder of the chemical additions. }\end{array}$ & & \\
\hline 9 & Add the potassium nitrate & 58.757 & g \\
\hline 10 & Add the sodium nitrate & 6.5626 & $\mathrm{~kg}$ \\
\hline 11 & Add the sodium nitrite & 2.0312 & $\mathrm{~kg}$ \\
\hline 12 & Add the sodium carbonate hydrate & 1.395 & $\mathrm{~kg}$ \\
\hline 13 & Add the Sodium sulfate & 361.907 & g \\
\hline 14 & Add the sodium phosphate tribasic dodecahydrate & 56.511 & g \\
\hline 15 & Add the sodium oxalate & 124.689 & g \\
\hline 16 & Add the sodium metasilicate nonahydrate & 59.183 & g \\
\hline 17 & Add the sodium formate & 63.294 & g \\
\hline 18 & Add DI water. & 20 & $\mathrm{~L}$ \\
\hline \multirow[t]{3}{*}{19} & Adjust the solution temperature to less than $30^{\circ} \mathrm{C}$. & & \\
\hline & Allow the solution to age for 72 hours before filtering. & & \\
\hline & $\begin{array}{l}\text { (NOTE: The solution should be in equilibrium long enough to avoid re- } \\
\text { precipitation. If re-precipitation occurs, a second aging followed by re-filtering } \\
\text { will be required.) }\end{array}$ & & \\
\hline 20 & $\begin{array}{l}\text { Filter the solution with a filter press or equivalent filtration system into an } \\
\text { agitated tank. Filter pore diameter need not be smaller than } 0.5 \mu \mathrm{m} \text {. The solids } \\
\text { removed are to be discarded. }\end{array}$ & & \\
\hline 21 & $\begin{array}{l}\text { Rinse down the mixing tank with DI water and filter. Combine this filtrate with } \\
\text { the filtrate from step } 20 .\end{array}$ & 0.05 & $\mathrm{~L}$ \\
\hline \multirow[t]{2}{*}{22} & $\begin{array}{l}\text { Rinse the filter system with DI water. Combine this filtrate with the filtrate from } \\
\text { step } 20 .\end{array}$ & 0.05 & $\mathrm{~L}$ \\
\hline & Allow solution to cool to room temperature. & & \\
\hline 23 & Add final DI water for a total of $45 \mathrm{~L}$ & Up to 5 & $\mathrm{~L}$ \\
\hline 24 & Remove $4 \mathrm{~L}$ and label as non-Cs Tank 49H simulant & & \\
\hline 25 & To the remaining $41 \mathrm{~L}$, add anhydrous $\mathrm{CsCl}$ and stir for $>24$ hours & 5.869 & g \\
\hline 26 & Withdraw samples from the $41 \mathrm{~L}$ for analyses by ICPMS and ICPES & & \\
\hline
\end{tabular}


9.2 Appendix B. Simulant Test Concentration of Inorganic Components (in mg/L) in Stage Samples

AQUEOUS

\begin{tabular}{|c|c|c|c|c|c|c|c|c|c|c|c|c|c|}
\hline Stage & 1 & 2 & 3 & 4 & 5 & Feed & 6 & 7 & 8 & 9 & 10 & 11 & 12 \\
\hline ELEMENT & \multicolumn{5}{|c|}{ Extraction } & & \multicolumn{2}{|c|}{ Scrub } & \multicolumn{5}{|c|}{ Strip } \\
\hline $\mathrm{Al}$ & 4600 & 4670 & 4570 & 4360 & 4720 & 5180 & 21.2 & $\mathrm{n} / \mathrm{a}$ & 0.92 & 1.34 & 0.41 & $<0.245$ & $<0.245$ \\
\hline $\mathrm{B}$ & $<2.68$ & $<2.68$ & $<2.68$ & $<2.68$ & $<2.68$ & $<3.43$ & 11.8 & $\mathrm{n} / \mathrm{a}$ & 104 & 98.3 & 101 & 106 & 102 \\
\hline $\mathrm{Ca}$ & $<3.15$ & $<3.15$ & $<3.15$ & $<3.15$ & $<3.15$ & $<3.29$ & 0.91 & $\mathrm{n} / \mathrm{a}$ & 0.43 & 0.33 & 0.43 & 0.38 & $<0.315$ \\
\hline Cs & 0.0240 & 0.0178 & 0.0316 & 0.233 & 3.250 & 83.1 & 219 & $\mathrm{n} / \mathrm{a}$ & 1140 & 613 & 274 & 100 & 12.8 \\
\hline $\mathrm{K}$ & 457 & 559 & 568 & 534 & 568 & 512 & 1040 & $\mathrm{n} / \mathrm{a}$ & 27.8 & 4.93 & $<2.43$ & $<2.43$ & $<2.43$ \\
\hline $\mathrm{Na}$ & 136000 & 140000 & 135000 & 129000 & 139000 & 151000 & 1930 & $\mathrm{n} / \mathrm{a}$ & 227 & 132 & 58.5 & 24.5 & 9.21 \\
\hline $\mathrm{P}$ & 93.9 & 100 & 95.9 & 89.1 & 101 & 95.4 & $<0.48$ & $\mathrm{n} / \mathrm{a}$ & $<0.48$ & $<0.48$ & $<0.48$ & $<0.48$ & $<0.48$ \\
\hline $\mathrm{S}$ & 1660 & 1640 & 1620 & 1570 & 1670 & 1910 & 6.3 & $\mathrm{n} / \mathrm{a}$ & 0.79 & 0.94 & $<0.735$ & $<0.735$ & $<0.735$ \\
\hline $\mathrm{Si}$ & 117 & 134 & 144 & 112 & 129 & 130 & 36.4 & $\mathrm{n} / \mathrm{a}$ & 3.38 & 3.94 & 4.11 & 5.43 & 3.59 \\
\hline $\mathrm{Zn}$ & 1.2 & 1.3 & 1.3 & 1.3 & 1.4 & 1.52 & $<0.09$ & $\mathrm{n} / \mathrm{a}$ & $<0.09$ & $<0.09$ & $<0.09$ & $<0.09$ & $<0.09$ \\
\hline
\end{tabular}

\section{ORGANIC}

\begin{tabular}{|c|c|c|c|c|c|c|c|c|c|c|c|c|c|}
\hline Stage & 1 & 2 & 3 & 4 & 5 & Feed & 6 & 7 & 8 & 9 & 10 & 11 & 12 \\
\hline ELEMENT & \multicolumn{5}{|c|}{ Extraction } & & \multicolumn{2}{|c|}{ Scrub } & \multicolumn{5}{|c|}{ Strip } \\
\hline $\mathrm{Al}$ & $<8.48$ & $<8.07$ & $<8.63$ & $<8.75$ & $<8.4$ & & 9.26 & $\mathrm{n} / \mathrm{a}$ & $<8.64$ & $<8.14$ & 9.28 & $<8.29$ & $<8.59$ \\
\hline $\mathrm{B}$ & $<4.16$ & $<3.96$ & $<4.23$ & $<4.3$ & $<4.12$ & & $<3.94$ & $\mathrm{n} / \mathrm{a}$ & $<4.24$ & $<4.0$ & $<3.65$ & $<4.07$ & $<4.22$ \\
\hline $\mathrm{Ca}$ & $<5.11$ & 12.7 & 48.4 & 11.2 & 23.7 & & $<7.27$ & $\mathrm{n} / \mathrm{a}$ & 6.11 & 14.8 & 21.4 & 38.7 & 13 \\
\hline Cs & 0.0454 & 0.042 & 0.0466 & 0.078 & 0.324 & & 0.489 & $\mathrm{n} / \mathrm{a}$ & 0.196 & 0.0878 & 0.0454 & 0.0337 & 0.0469 \\
\hline $\mathrm{K}$ & 289 & 346 & 325 & 305 & 325 & & $<35.8$ & $\mathrm{n} / \mathrm{a}$ & $<38.5$ & $<36.3$ & $<33.1$ & $<36.9$ & $<38.3$ \\
\hline $\mathrm{Na}$ & 69.3 & 63.4 & 62.8 & 43.6 & 72.9 & & $<12.3$ & $\mathrm{n} / \mathrm{a}$ & $<13.3$ & $<12.5$ & $<11.4$ & $<12.8$ & $<13.2$ \\
\hline $\mathrm{P}$ & $<7.46$ & $<7.1$ & $<7.58$ & $<7.7$ & $<7.38$ & & $<7.05$ & $\mathrm{n} / \mathrm{a}$ & $<7.59$ & $<7.16$ & $<6.54$ & $<7.29$ & $<7.55$ \\
\hline $\mathrm{S}$ & 39.2 & 42.4 & 39.4 & 38.3 & 41.1 & & 41.7 & $\mathrm{n} / \mathrm{a}$ & 37.9 & 38.8 & 42 & 43.6 & 41.6 \\
\hline $\mathrm{Si}$ & 55.5 & 89.1 & 136 & 69 & 29 & & 48.2 & $\mathrm{n} / \mathrm{a}$ & 26.6 & 25 & 35.5 & 24 & 47.5 \\
\hline $\mathrm{Zn}$ & $<1.4$ & $>1.3$ & 1.71 & $<1.44$ & $<1.38$ & & $<1.3$ & $\mathrm{n} / \mathrm{a}$ & $<1.4$ & $<1.3$ & $<1.2$ & $<1.4$ & $<1.4$ \\
\hline $\mathrm{n} / \mathrm{a}=$ sample & mpromise & & & & & & & & & & & & \\
\hline
\end{tabular}




\section{Distribution:}
A. B. Barnes, 999-W
S. D. Fink, 773-A
B. J. Giddings, 786-5A
C. C. Herman, 999-W
S. L. Marra, 773-A
F. M. Pennebaker, 773-42A
J. C. Griffin, 773-A
M. L. Crowder, 773-A
D. J. Pak, 773-41A
T. B. Peters, 773-42A
R. A. Pierce, 773-A
K. M. Taylor-Pashow, 773-A
A. L. Washington, 773-42A
R. W. Blessing, 773-A
P. L. Lee, 703-41A
W. R. Wilmarth, 773-A
F. F. Fondeur, 773-A
R. E. Edwards, 773-67A
M. W. Geeting, 241-152H
B. A. Gifford, 704-56H
B. A. Oard, $241-197 \mathrm{H}$
A. Samadi, 241-197H
S. McLeskey, 241-152H
D. J. Martin, 241-152H
E. J. Freed, 704-56H
W. B. Brasel, 992-2W
C. Conner, Parsons
R. D. Lentsch, Parsons
M. S. Brugh, Parsons
T. D. Burns, Parsons
A. N. Singer, Parsons
M. J. Thomas, Parsons
R. J. Schepens, Parsons
R. K. Leugemors, 992-5W
P. G. Suggs, 704-S
P. Jackson, 703-46A
B. A. Moyer, ORNL
L. H. Delmau, ORNL
J. F. Birdwell, ORNL
R. A. Leonard, ANL 